NBER WORKING PAPER SERIES

\title{
WHEN IS THERE A STRONG TRANSFER RISK FROM THE SOVEREIGNS TO THE CORPORATES? PROPERTY RIGHTS GAPS AND CDS SPREADS
}

\author{
Jennie Bai \\ Shang-Jin Wei \\ Working Paper 18600 \\ http://www.nber.org/papers/w18600
}

\author{
NATIONAL BUREAU OF ECONOMIC RESEARCH \\ 1050 Massachusetts Avenue \\ Cambridge, MA 02138
}

December 2012

The project is funded by the Federal Reserve Bank of New York and Columbia Business School. We thank Jian Gao, Joy Glazener, Steve Kang, and Nikhil Patel for excellent research assistance, and participants at various seminars and conferences for helpful discussions. The authors can be contacted via jennie.bai@ny.frb.org and shangjin.wei@columbia.edu. The views presented here are solely those of the authors and do not necessarily represent those of the Federal Reserve Bank of New York or any other institutions with which the authors are affiliated. The views expressed herein are those of the authors and do not necessarily reflect the views of the National Bureau of Economic Research.

NBER working papers are circulated for discussion and comment purposes. They have not been peerreviewed or been subject to the review by the NBER Board of Directors that accompanies official NBER publications.

(C) 2012 by Jennie Bai and Shang-Jin Wei. All rights reserved. Short sections of text, not to exceed two paragraphs, may be quoted without explicit permission provided that full credit, including $\odot$ notice, is given to the source. 
When Is There a Strong Transfer Risk from the Sovereigns to the Corporates? Property Rights

Gaps and CDS Spreads

Jennie Bai and Shang-Jin Wei

NBER Working Paper No. 18600

December 2012

JEL No. F3,G1,G3,O43

\begin{abstract}
When a sovereign faces the risk of debt default, it may be tempted to expropriate the private sector. This may be one reason for why international investment in private companies has to take into account the sovereign risk. But the likelihood of a transfer from the sovereign risk to corporate default risks may be mitigated by legal institutions that provide strong property rights protection. Using a novel credit default swaps (CDS) dataset covering both government and corporate entities across 30 countries, this paper studies both the average strength of the transfer risks and the role of institutions in mitigating such risks. We find that (1) sovereign risk on average has a statistically and economically significant influence on corporate credit risks. All else equal, a 100 basis points increase in the sovereign CDS spread leads to an increase in corporate CDS spreads by 71 basis points. (2) The sovereign-corporate relation varies across corporations, with state-owned companies exhibiting a stronger relation. (3) However, strong property rights institutions tend to weaken the connection. In contrast, contracting institutions (protection of creditor rights or minority shareholder rights) do not appear to matter much in this context
\end{abstract}

Jennie Bai

Federal Reserve Bank of New York

Capital Market Function, Research Group

33 Liberty St.

New York, NY 10045

jennie.bai@ny.frb.org

Shang-Jin Wei

Graduate School of Business

Columbia University

Uris Hall 619

3022 Broadway

New York, NY 10027-6902

and NBER

shangjin.wei@columbia.edu 
"Fears that Spain may suffer a similar debt crisis to Greece are raising funding costs for companies... There's a good reason to be concerned because as sovereign spreads go wider, it's raising the cost of funding for corporates." - Reuters, May 7, 2010

\section{Introduction}

The Greek fiscal difficulties during 2011-2012 have shined a spotlight not only on the risk of sovereign debt default, but also on the potential spillovers to corporate defaults. As the spreads on Greece's sovereign credit default swaps (CDSs) soared, the yields on its corporate bonds also surged. As indicated by the opening quote, it is tantalizing to think that there is a strong link between the rising costs of insuring against corporate default and a deteriorating sovereign debt environment. The objective of this paper is to study when such a link is strong and when it is weak.

Although anecdotes suggest a high correlation of default risk between sovereigns and corporations, there is surprisingly little empirical work to investigate this relation. We note that there exists no mechanical relationship between the two: if a government is not able to meet its debt obligation, corporate fundamentals can still be strong enough with no increase in the probability of default. One does not normally observe such a connection between government and corporate credit risk in the developed economies, since there is essentially no sign of sovereign credit risk in advanced countries in most recent decades (Reinhart and Rogoff (2009)). However, the lack of connection may not be the case in the recent global crisis.

Using a novel data set on spreads of credit default swaps (CDS) for governments in 30 countries and 2745 corporations in these countries, we study in this paper possible "transfers" from sovereign to corporate default risks and possible roles of institutions in mitigating the risks. Our use of the CDS data differs from the common methodology in the literature that typically studies 
the determinants of sovereign risk in the government bond market (Bernoth, Hagen, Schuknecht (2006), Hilscher and Nosbusch (2010), Longstaff, Pan, Pedersen, and Singleton (2008)), as well as the determinants of corporate risk using corporate bond yields. ${ }^{2}$ Also using bond data, a small number of papers have studied the impact of sovereign risk on corporate credit risk, including Peter and Grandes (2005), Durbin and Ng (2005), and Dittmar and Yuan (2008). This line of research is limited to emerging market countries, and does not examine the role of institutions in mitigating the transfer risks.

Our use of CDS spreads rather than bond yields has a number of advantages. First, sovereign CDS spread often is a better proxy for sovereign credit risk. While government bonds are often denominated in a local currency, sovereign CDS is usually traded in a foreign currency which tends to protect the purchasers against inflation risk and foreign exchange risk. For example, the United States sovereign CDS is denominated in the Euro, so that U.S. dollar inflation following a credit event should not by itself erode the value of a CDS contract in a foreign currency. ${ }^{3}$ On the contrary, government bonds, issued by a national government and usually denominated in domestic currency, often contain inflation risk (unless it is indexed to inflation, which is not common).

Second, sovereign CDS is an over-the-counter contract settled in the credit derivative market and the market price cannot be easily manipulated by the government. The government cannot buy or sell credit default swap protection on its own bonds given the obvious counterparty risk. Hence sovereign CDS spread mainly indicates the credit quality perceived by market investors. Government bond yields, however, can be manipulated through the timing of issuance or buyback, and through the issuance amount.

Third, the difference between sovereign CDS and corporate CDS is typically smaller than that between sovereign and corporate bond yields. It is well documented in the literature that corporate

\footnotetext{
${ }^{2}$ There is a vast literature to explain the determinants of corporate bond credit spread, including Huang and Huang (2003), Eom, Helwege, and Huang (2004), Collin-Dufresne, Goldstein, and Martin (2001).

${ }^{3}$ In addition to the United States, Switzerland sovereign CDS is also denominated in Euros. All other countries in the data set, those from Europe, Australia, and Asia, have their sovereign CDS traded in US dollars.
} 
bonds contain risks in addition to default risk (see Collin-Dufresne, Goldstein, Martin (2001), and Bongaerts, De Jong, Driessen (2011) among others). The liquidity in the government bond market is typically much higher than the liquidity in corporate bond market. The credit default swap market, however, consistently captures credit risk no matter if it is for sovereign or corporate. Therefore the international CDS data provides a better measure to test the sovereign-corporate relationship than government and corporate bonds. As the CDS market has a much shorter history than bonds, however, the existing literature typically uses only bond data to examine the impact of sovereign governance on the corporate sector. In so doing, researchers need to control for firm-specific characteristics since corporate bond yields contain a mixture of risks including credit risk, liquidity risk, jump risk, and taxation effects. The CDS data, on the other hand, provides a straightforward channel to explore the sovereign-corporate credit risk relationship.

Our goal of studying the role of institutions in the sovereign-corporate default connection is also novel in the literature. The political-economy logic underlying the transmission of sovereign default risk to corporations is as follows. If a government is short of money, it could either persuade the central bank to inflate away the government debt, or more likely, pass the debt problem onto the corporate sector by raising tax revenue. In other words, when the state is in fiscal trouble, it could forcefully expropriate the private sector by raising the tax rate or engaging in a number of fiscal maneuvers. Not all governments have the ability to expropriate the private sector, at least not to the same extent. A natural hypothesis to examine is whether the pass-through is lower in countries with stronger institutions that constrain the ability of the government to change its taxation system at its discretion. In other words, do stronger institutions translate into a weakened relationship between sovereign-corporate credit risk? In answering this question, we will also pay attention to possible differences between property rights institutions and contracting institutions. Our hypothesis is that property rights institutions are more important in this context than contracting or creditor rights institutuions.

We preview our main findings here. First, sovereign risk on average has a statistically and 
economically significant influence on corporate credit risk. All else equal, a 100 basis points (bps) increase in sovereign CDS spread leads to an increase in corporate CDS spread by $71 \mathrm{bps}$. Second, the sovereign-corporate relation varies across corporations. State-owned companies, both in financial and non-financial sectors, tend to have a stronger sovereign-corporate relation. The elasticity of state-owned companies is on average 47 bps higher than that of non-state-owned companies. Third, country-level institutions matter but it is important to distinguish between property rights institutions and contracting institutions. Specifically, those institutions that place an effective check and balance on the government tend to weaken the connection between sovereign and corporate credit risks. On the other hand, institutions that are mainly designed to strengthen protection of creditor rights or minority shareholder rights do not appear to matter much in this context. This is perhaps not surprising, and is nicely linked to Douglas North's notion that one needs to separate property rights institutions and contracting institutions (see Acemoglu and Johnson (2006) for a recent empirical test in the context of economic growth).

This paper is related to several strands in the literature. Attinasi, Checherita and Nickel (2009), Alter and Schueler (2011), and Ejsing and Lemke (2011) study the effect of bank bailouts on sovereign credit risk. Dieckmann and Plank (2011) document the strong explanatory power of the state of the financial sector on sovereign CDS spreads around the crisis. Acharya, Drechsler and Schnabl (2011) provide empirical evidence on the relation between financial and sovereign credit risk for the Eurozone countries during 2007-2010. None of the papers has used CDS spreads to explore the relationship between corporate and sovereign risks. Separately, there is a large literature that investigates the consequences of contracting and property rights institutions, including La Porta, et al. (2003) and Djankov et al. (2007), though none has explored the role of institutions in mitigating the link between corporate and sovereign risks. In terms of novelty of our contributions, we reiterate that we use CDS spreads to explore possible transfer risks from sovereign risks to corporate defaults. We are also the first to not only explore the role of institutions in this context but also to distinguish different types of institutions. 
The paper is organized in the following way. In Section 2, we explain our basic empirical specification, the fundamentals of the CDS market, and the sources of our key data. In Section 3, we present the main empirical results. This is followed by Section 4, which provides robustness checks. In Section 5, we conclude.

\section{Research Design and Data}

We first spell out our empirical specifications that investigate the relationship between the corporate and sovereign default risks and the role of institutions in weakening the relationship. We then provide details on the working of the CDS market and the sources of our key data.

\subsection{Empirical specifications}

To formally test the impact of sovereign risk on corporate credit risk, we propose the following regression:

$$
\Delta C D S_{i, k, t}=\alpha_{i}+\delta_{t}+\beta \Delta C D S_{k, t}+\gamma^{\prime} \Delta Z_{i, k, t}+\varepsilon_{i, k, t},
$$

where $C D S_{i, k, t}$ denotes the 5-year CDS spread on company $i$ in country $k$ at time $t, \Delta C D S_{i, k, t}=$ $C D S_{i, k, t}-C D S_{i, k, t-1}$ denotes the change of the CDS spread from $t-1$ to $t ; C D S_{k, t}$ denotes the 5-year CDS spread on country $k$ at time $t$, and $\Delta C D S_{k, t}$ denotes the corresponding increase in the sovereign CDS spread from $t-1$ to $t ; \alpha_{i}$ is a dummy variable denoting the fixed effect for country, $\delta_{t}$ is the time fixed effect in a monthly frequency; $\Delta Z_{i, k, t}$ are the changes in the control variables from $t-1$ to $t$.

In the benchmark model, we assume $\beta=\beta_{0}$, which is a single parameter (i.e., invariant to 
company or country) to estimate. In the extension, we let

$$
\beta=\beta_{0}+\beta_{1} \text { Inst }_{1, k}+\cdots+\beta_{s} \text { Inst }_{s, k}
$$

and extend the basic regression (1) to

$$
\Delta C D S_{i, k, t}=\alpha_{i}+\delta_{t}+\beta_{0} \Delta C D S_{k, t}+\sum_{s} \beta_{s} \text { Inst }_{s, k} \cdot \Delta C D S_{k, t}+\gamma^{\prime} \Delta Z_{i, k, t}+\varepsilon_{i, k, t}
$$

where $I_{n s t} t_{s, k}$ is the $s$-th instrument of institutional quality for country $k$. We will examine both contracting institutions (protection of minority shareholders or protection of creditor rights) and property rights institutions (constitutional constraint on the power of the government) which will be introduced later in this section.

\subsection{Credit Default Swaps}

A credit default swap (CDS) is a financial derivative contract which functions as an insurance against credit events that happen to a reference entity such as a corporate company. One special type of reference entity is the sovereign government and the reference obligation for a sovereign credit default swap contract is designated as senior external debt or international debt.

To illustrate how a sovereign CDS works, consider the case of the United States. The spread for a five-year CDS contract on the U.S. government rose to 100.25 basis points on March 6, 2009, for the first time ever passing the psychological barrier of 100 basis points. This means a trader would have to pay EUR 100,250 a year to insure a notional EUR 10 million of United States federal government debt for a pre-contracted credit event. ${ }^{4}$ If no such credit event happens, the protection

\footnotetext{
${ }^{4}$ According to the International Swap and Derivative Association, credit events in the case of corporate default swap include bankruptcy, obligation acceleration, obligation default, and restructuring. As many governments have never defaulted in a pure technical sense, credit events in the case of sovereign credit default swaps are defined somewhat differently to take into account all events that have the equivalent effect as a technical default, including failure to pay on the coupons or principals of treasury bonds, debt restructuring, repudiation and moratorium.
} 
buyer would pay this annuity for the full five-year horizon of the contract. If a credit event happens, however, the protection buyer could sell the sovereign bond to the protection seller at the par value (or obtain the cash equivalent of the net gain), and terminate the contract. Of course, a corporate CDS works similarly except that the reference entity would be a corporation.

The market for sovereign credit default swaps has been growing rapidly since the financial crisis, especially during the recent sovereign debt crisis. According to the Depository Trust \& Clearing Corporation, the notional outstanding volume of Italian sovereign CDS on March 12, 2010 totals US\$223.3 billion compared to US\$162.4 billion on March 13, 2009. Spanish sovereign CDS increased from US\$66.6 billion in March 2009 to US\$102 billion in March 2010; Greek sovereign CDS doubled to US\$78 billion from March 2009 to March 2010.

The growing interest in the sovereign CDS market is fueled by ballooning budget deficits in developed countries, particularly Greece, Portugal, Italy, Spain and Ireland. Meanwhile, the widening sovereign CDS spreads seem to have an influence on the corporate credit market. In Figure 1, the sovereign CDS for the United States and Canada have widened substantially since the summer of 2007, indicating that their 'default' is perceived to be more likely, and hence a protection from such a 'default' by those countries is becoming more valuable. The Markit CDX North America Investment-Grade Index (CDX NA. IG) follows the trend of the U.S. and Canadian sovereign CDS. In Europe, we also observe a tight co-movement of sovereign CDS and corporate CDS, represented separately by the Markit iTraxx SovX Western Europe Index (on the debt of 15 governments) and the Markit iTraxx Europe CDS Index (on 125 investment-grade firms) and the Markit iTraxx Crossover CDS index (on 50 high-yield firms).

\subsubsection{International data on CDS spreads}

We collect the international credit default swap data from the Markit Group. The data set contains 3.2 million daily observations across thirty-six countries, spanning the period from January 2, 
2001 to February 16, 2010. Filtering out countries with stale or incomplete data, we finally focus on thirty countries. We use the data before January 1, 2008 only as a background check while we focus on the period of January 1, 2008 to February 16, 2010 to test our hypothesis, since international-level government intervention started at the beginning of 2008. (See Appendix A for the historical co-movement between sovereign CDS and corporate sector CDS since January 2002.)

Country and Corporate Coverage For a country to be qualified in our sample, we require it to have at least 10 entities. In so doing we delete small countries with infrequent CDS transactions, which would have added noise to our study. We also cross out observations with a CDS price over 10000 basis points, as they are either suspected of data entry errors or indicate a firm close to or already in bankruptcy. We also require a country to have more than 250 daily observations in the test period between 1/2/2008 - 2/16/2010. We end up with 30 countries covering major developed and emerging-market regions. Among them the top five countries with the most entities are the United States (1314 entities), Japan (431 entities), the United Kingdom (229 entities), Germany (109 entities), and France (91 entities). Panel A in Table 1 lists all thirty countries and reports the number of firm-day observations, the number of reference entities, the average CDS price as well as the sovereign CDS price in each country. Panel B reports the distribution of CDS entities across sectors and by regions. Out of 2745 reference entities, Asia (including Japan) has 21 percent with 579 entities, Europe takes 28 percent with 769 entities, and North America (the U.S. alone) takes 48 percent with 1314 entities. By industry sector, the financial sector includes 638 entities or 23 percent of the total, and the government sector holds 171 entities, about 7 percent.

Each international credit default swap contract needs to set up a transaction currency and a restructuring documentation clause. Under the 2003 Credit Definitions by the International Swap and Derivative Association (ISDA), there are four types of restructuring clauses: Cumulative Restructuring (CR), Modified Restructuring (MR), Modified-Modified Restructuring (MM), and No 
Restructuring (XR). ${ }^{5}$ A CDS contract can be in any of the four documentation clauses, and using any currency such as USD/EUR/AUD/ JPY. It is challenging to construct an internationally comparable sample with the right currency and document clause in the face of multiple choices.

Over time, however, CDS contracts have come to trade on a market-defined convention. We use the Markit convention rule to construct our data set. For example, Europe's CDS contracts typically trade with an MM restructuring convention, North American entities trade with an XR convention, ${ }^{6}$ Emerging markets and Asian market trade with a CR convention, and all sovereign CDS trade with the CR convention. The different convention rule in the international CDS market basically is determined by the local law in terms of bankruptcy. In Europe, Modified-Modified restructuring is common because the laws make it difficult for borrowers to file bankruptcy in many jurisdictions. Restructuring and reorganization outside a process similar to Chapter 11 bankruptcy in the U.S. is for stressed European companies. For North American investment-grade credits, Modified restructuring addressed the historic needs of hedgers of bank loan portfolios. With the growth of the CDS market, hedgers of bank loan portfolios have become a smaller percentage of the overall CDS market. As such, the industry has considered dropping restructuring as a North American convention and decided to exert the no-restructuring clause on April 8, 2009 (based on the information of the User Guide at Markit.com).

In terms of currency, we choose the Euro-dominated sovereign CDS contract for the United

\footnotetext{
${ }^{5}$ Initially, any restructuring qualified as a credit event as cumulative restructuring was introduced as the standard contract term in the 1999 ISDA definition. The cumulative-restructuring (CR) clause allows the protection buyer to deliver bonds of any maturity after restructuring of debt in any form occurs. Introduced in 2001, the modifiedrestructuring (MR) clause has become common practice in North America, which limits deliverable obligations to bonds with a maturity of 30 months or less after a restructuring. The modified-modified-restructuring (MM) clause, introduced in 2003, is a "modified" version of the modified restructuring option, which resulted from the criticism of the modified restructuring that it was too strict with respect to deliverable obligations. Under the modified-modified restructuring, which is more popular in Europe, deliverable obligations can be maturing in up to 60 months after a restructuring. The no-restructuring (XR) clause excludes all restructuring events under the contract as "trigger events," eliminating the possibility that the protection seller suffers a "soft" credit event that does not necessarily result in losses to the protection buyer.

${ }^{6}$ North American Investment Grade names usually trade with a modified restructuring (MR) clause, and North American High Yield names trade without restructuring (XR). Since April 8, 2009, all North American entities trade with an XR convention. This is called the CDS Big Bang event. We follow the changing convention rule in our data set.
} 
States, and the dollar-dominated contract for all other countries. Finally, we choose the five-year CDS spread from a term structure of maturities as this typically has the most liquidity. We also target CDS contracts on senior unsecured debt, noted as "SNRFOR" in the data set.

Sector Markit adopts the Industry Classification Benchmark (ICB) to classify reference entities. First, the entities are noted whether they are government related or not. Second, the ICB sector classification decomposes non-government entities into the following ten categories: (1) Financials; (2) Health Care; (3) Oil \& Gas; (4) Telecommunications; (5) Basic Materials; (6) Utilities; (7) Industrials; (8) Technology; (9) Consumer Goods; and (10) Consumer Services. In addition, Markit adds one more category for government.

We disaggregate the government sector into three sub-sectors: state-owned financials, stateowned non-financials and local government. State-owned financials refer to national banks such as Bank of Greece, Development Bank of Japan, Federal Home Loan Bank, and financial service institutes like Dubai international financial center. State-owned non-financials are mainly national utilities (water, electricity, and power) as well as infrastructural agencies such as Russian Railways and Deutsche Bahn. Local government sub-sectors includes state/province, regional agencies, and municipalities such as the State of New York, Hiroshima Perfecture, Ville de Montreal, Emirate of Abu Dhabi.

\subsection{Data on Institutional Quality}

There is a growing consensus among economists and political scientists that the social, economic, legal, and political organizations of a society, that is, its "institutions," are determinants of economic performance in the private sector. Good institutions simultaneously support private contracts

\footnotetext{
${ }^{7}$ Seniority levels of debt in CDS contracts include (1) secured debt (SECDOM), (2) senior unsecured debt for Corporate and Financial, and Sovereign debt for Government (SNRFOR), (3) subordinated or lower tier 2 debt for banks (SUBLT2), (4) junior subordinated or upper tier 2 debt for banks (JRSUBUT2), and (5) preference shares or tier 1 capital for banks (PREFT1). Among them, SNRFOR is the dominant form in the data set.
} 
and provide checks against expropriation by the government (Acemoglu and Johnson (2005)). The corporate governance literature offers potential instruments for institutional behavior, for example, Djankov, McLiesh, and Shleifer (2007), Djankov, La Porta, Lopez-de-Silanes, and Shleifer (2003) and early works by La Porta, Lopez-de-Silanes, Shleifer and Vishny (1997, 1998). We use these proxies to measure the ease of transferring sovereign risk to private credit markets. Intuitively, if a country has stronger legal protection for investors in terms of both law and enforcement, there would be less "sovereign grabbing-hand" risk for the corporate sector. In this paper, we use the following five measures of institutional quality.

- Constraints on Executive, captures the degree of constraints on politicians and politically powerful elites (Gurr (1997), Acemoglu and Johnson (2005)). We collect the data from the Policy IV data set (www.systemicpeace.org) and take the average value between 2000 and 2008. The higher scores indicate more constraints on politicians. Most democratic countries such as the United States and European countries have high scores.

- Control of Expropriation Risk, according to the international country risk rating agency ICR, measures the risk of "outright confiscation" or "forced nationalization." The data source is La Porta et al. (1998). It is the average of the monthly index between 1982 and 1995, scaled from zero to ten. Lower scores indicate higher expropriation risk.

- Credit Right Index, measures the legal rights of creditors against defaulting debtors, and is interpreted as a measure of creditor power. While the idea was first proposed by La Porta et al. (1997, 1998), we employ the revised and updated data from Djankov et al. (2007). The index ranges from zero to four.

- Contract Enforcement Days, the number of days to resolve a payment dispute through courts, measures the inefficiency of the legal system. We collect the data also from Djankov et al. (2007). The longer the contract enforcement day, the less the efficiency of the legal system. 
- Rule of Law, an assessment of the law and order tradition in a country, capturing the perception of the extent to which agents have confidence in and abide by the rules of society, and in particular the quality of contract enforcement and property rights. The data are from the Worldwide Governance Indicators (WGI) website (www.govindicators.org). We take the average value over 2000 - 2008. Lower scores means weaker tradition for law and order.

Table 2 summarizes the institutional measures. Panel A reports the country-level scores for five measures of institutions: constraints on executive, control of expropriation risk, credit right index, contract enforcement days, and rule of law. We assign countries to Group 1 (Good Property Rights Institution) if their values in all three measures of property rights institutions: Constraint on Executive, Control of Expropriation Risk, and Rule of Law, exceed the median value, and countries to Group 2 (Bad Property Rights Institution) if these values are all lower than the mean value. The remaining countries are in Group 3, which have mixed quality of property rights institution. Panel B shows their correlation values. Rule of law and control of expropriation risk are significantly and positively correlated by a value of 0.86 . All other correlations are relatively small. The contract enforcement day is negatively correlated with the remaining four variables yet not significant.

\section{Empirical Tests}

\subsection{A Preliminary Look at the Average Pattern across Countries}

Let us start with simple correlations between corporate and sovereign credit default swaps for each country in the sample period of January 2008 to February 2010. Figure 2 graphically highlights the overwhelming positive sovereign-corporate correlations. The correlations appear stronger for the emerging-market economies. The top five countries in terms of correlations are Malaysia (0.69), Philippines (0.52), Korea (0.52), Mexico (0.49), and Russia (0.40). The bottom five countries in 
this regard are the United States (0.03), Norway (0.05), Japan (0.05), Belgium (0.06), and Germany (0.07).

We further test whether firm and country characteristics have an influence on the sovereigncorporate credit risk relationship. Our regression specification has the change in corporate CDS as the dependent variable, with the change in sovereign CDS and its intersection with firm or country characteristics as the regressors. Column (1) in Table 3 shows that an increase in the sovereign CDS spread by 100 basis points is on average associated with an increase in corporate CDS spread by 71 basis points. Column (2) examines whether and how the response of the corporate CDS spreads depends on the type of corporations. We consider four types of corporations: local government entities, state-owned financial firms, state-owned non-financial firms, and non-state-owned financial firms. Though media reports suggest that the financial sector is particularly tied to sovereign risk, we find that only state-owned firms are affected by sovereign risk, but not non-state-owned financial firms. The elasticity of state-owned companies, both in financial and non-financial sectors, is on average 47 basis points higher than that of non-state-owned companies. Interestingly, CDS reference entities categorized as local government (such as state, province, prefecture, city, etc.) are not significantly tied to the sovereign environment.

Columns (3)-(5) examine if a country's or a firm's fundamental has any impact on the sovereigncorporate relation. We use the lagged CDS spread to capture the credit risk for a country or a firm. If the widening of firm credit default swaps results from the deterioration of that firm's fundamentals or from bad economic conditions, then we should expect a weaker impact directly from the sovereign CDS spread change but a significant coefficient in the intersection of lagged country/firm CDS spread and the change in the sovereign CDS. However we don't find such evidence. The coefficients for the controlling variables, both lagged country risk and lagged firm credit risk, are economically small and statistically insignificant.

Finally, Column (6) of Table 3 tests whether the seemingly stronger sovereign-corporate rela- 
tion in the emerging-market countries is true. We classify countries according to a joint consideration of MSCI membership and Dow Jones emerging-market lists. There are ten countries out of thirty categorized in the emerging markets in our sample. The regression coefficient is 0.04 with a standard deviation of 0.12 , small and insignificant. The result is robust controlling for the sectors of reference entities, as shown in Column (7).

Given that there is no significant difference between developed and emerging-market countries, a natural question is what other country characteristics can explain the cross-sectional heterogeneity of the sovereign influence on the perceived corporate default. We investigate the role of country-level institutions in the next subsection.

\subsection{Beyond the Average Pattern: Role of Country-level Institutions}

We now turn to the role of public institutions. As recognized by North (1981) and Acemoglu and Johnson (2005), for many economic questions, it is important to distinguish between property rights institutions and contracting institutions. Contracting institutions are the rules and the norms governing reliable execution of contracts between private parties. For example, a debt contract between a creditor and a debtor is expected to be more reliably executed in a country with better contracting institutions. In comparison, property rights institutions are rules and norms that constrain the ability of the state from arbitrarily expropriating the private sector. The stronger the property rights institutions, the less likely the private sector needs to fear unfair treatment by the government and political elites.

Table 4 examines the role of these institutions on the sovereign-corporate credit risk relationship. Property rights institutions are represented by constraint on executive, control of expropriation risk, and rule of law. Contracting institutions are measured by creditor rights index and contract enforcement days. 
All indices are defined in Section 3.2. Based on the value of each index except for the constraint on the executive branch, countries are grouped into three quantiles (Q1 - Q3) according to the distribution of their values across countries. The index on constraints on the executive branch is divided into two quantiles due to its narrower distribution than the other indices; while its median and mean values are 7 and 6.17, respectively, its standard error of 1.43 is relatively small. For all indices, the indices are organized in such a way that a low value corresponds to a low quality of institutions. For example, Q1 is a dummy variable referring to the group of countries which have the lowest quality of institutions.

In Column (1), Panel A of Table 4, we examine the role of property rights protection as represented by the constraint on the executives (which is a binary variable). The coefficient on the change in country-level CDS continues to show a positive association between corporate-level and sovereign-level CDS spreads. However, for the interactive term between the index for property rights protection and the change in the sovereign CDS spread, the coefficient is negative $(-0.25)$ and statistically significant. This means that stronger protection of property rights at the country level tends to weaken the association between the corporate and sovereign CDS spreads.

In Column (2) of the same table, protection of property rights is represented by the index on the control of expropriation risks. The coefficients on the two interaction terms are negative; only the coefficient on the interactive term between Q3 of the property rights index and the change in sovereign CDS is statistically significant at the $1 \%$ level. This also suggests better property rights protection translates into a weaker association between country-level and corporate-level CDS spreads, especially for countries that are in the top percentile of the distribution for the control of expropriation risks.

In Column (3) of the same table, we use the index on rule of law as the measure for property rights protection. The negative coefficients on the two interactive terms are consistent with the idea that better rule of law reduces the association between corporate-sovereign CDS spreads. However, 
these coefficients are not statistically significant.

In Panel B of Table 4, we switch to contracting institutions. In Column 1, we focus on creditor rights and examine the role of the interaction between the index for creditor rights and the sovereign CDS. We find the coefficients on the two interactive terms to be insignificantly different from zero.

In Column 2, we use the number of days it takes to enforce a contract as a measure of the reliability of the contracting institutions. Again, the coefficients on the interactive terms are not different from zero. In other words, there is no evidence that better or worse contracting institutions materially affect the relationship between corporate and sovereign CDS spreads.

To summarize, we find evidence that property rights institutions, but not contracting institutions, tend to weaken the association between default risks at the corporate and country levels.

\section{Additional Robustness Checks}

\subsection{Price Discovery}

We have shown that firms' credit risk is significantly affected by the credit risk of their sovereign government. There exists the possibility that corporate credit risk may also have an impact on corresponding sovereign risk. The deterioration of corporate fundamentals or liquidity can force the government to take over the risk from the private sector, and hence the government bears more sovereign risk. In principle, there can be two-way effects of one default risk on the other. How do we know that the empirical relationship we have reported early mainly reflects the effect of a change in sovereign risk on a change in corporate risk?

One standard approach might be to run a system of simultaneous equations, or an instrumental variable regression. Unfortunately, we are not able to come up with variables that are convincingly exogenous but still strongly correlated with the sovereign risks. A second approach might be an 
event study: if there is a set of clearly exogenous events that cause the sovereign CDS spread to increase but otherwise do not directly affect corporate default risks, we can study how corporate CDS spreads respond to such events. A surprising failure of a Greek negotiation to secure an IMF/ECB loan might qualify for such an event. Unfortunately, there is a scarcity of such events with enough surprise components for us to construct a statistically powerful event study.

In this section, we report a third approach that we find feasible to implement. In particular, we make use of the "price discovery" tools developed in the asset pricing literature and seek to quantify, when both sovereign and corporate CDS spreads increase, which of the two markets contribute more to the joint price discovery process. If the innovations in the sovereign CDS market are the primary contributor to the price discovery, we interpret it as evidence that an important part of the correlation reflects a causal effect from the sovereign CDS spread to corporate CDS spreads. Conversely, if the innovations in the corporate CDS market are the main contributor, we interpret it in the opposite way.

Following Yuan (2005), we run the following two common factor models in a vector errorcorrection form:

$$
\begin{aligned}
\Delta \ln (C D S)_{j, t}^{S}= & \lambda_{1, j}\left(C D S_{j, t-1}^{S}-\alpha_{0, j}-\alpha_{1, j} C D S_{j, t-1}^{C}\right) \\
& +\sum_{i=1}^{p} \beta_{1, j, i} \Delta \ln (C D S)_{j, t-i}^{S}+\sum_{i=1}^{p} \delta_{1, j, i} \Delta \ln (C D S)_{t-i}^{C}+\varepsilon_{1, j, t}, \quad \forall j \\
\Delta \ln (C D S)_{j, t}^{C}= & \lambda_{2, j}\left(C D S_{j, t-1}^{S}-\alpha_{0, j}-\alpha_{1, j} C D S_{j, t-1}^{C}\right) \\
& +\sum_{i=1}^{p} \beta_{2, j, i} \Delta \ln (C D S)_{j, t-i}^{S}+\sum_{i=1}^{p} \delta_{2, j, i} \Delta \ln (C D S)_{j, t-i}^{C}+\varepsilon_{2, j, t}, \quad \forall j
\end{aligned}
$$

where $C D S_{j}^{S}$ is the sovereign credit-default swap of country $j$, and $C D S_{j}^{C}$ is the equal-weighted portfolios of corporate credit-default swaps in country $j$.

Based on the parameter estimates, two separate measures are constructed to gauge the contributions of sovereign credit risk to the price discovery of common credit risk: the permanent factor 
indicator by Gonzalo and Granger (1995) and the "information share” by Hasbrouck (1995, 2003).

The Gonzalo and Granger measure ignores the correlation between the two markets and attributes superior price discovery to the market that adjusts least to price movements in the other market. It is defined as

$$
G G_{j}=\frac{\lambda_{2, j}}{\lambda_{1, j}-\lambda_{2, j}}
$$

where the $\lambda$ coefficients reveal which of the two markets leads in terms of price discovery.

The Hasbrouck information share indicator assumes that price volatility reflects new information, and thus the market that contributes most to the variance of the innovations to the common factor is also presumed to contribute most to price discovery. To obtain the contributions of shocks to sovereign CDS markets on the permanent component of credit information, we follow Hasbrouck and perform a Choleski decomposition on the covariance matrix of the residuals, $\Omega=E\left[\varepsilon_{t} \varepsilon_{t}^{\prime}\right]$, to find a lower triangular matrix $M$, whose $i, k$-th element we denote $m_{i k}$, such that $M M^{\prime}=\Omega$. We now define, in the same manner as Baillie et al. (2002), the Hasbrouck information share for the sovereign credit market,

$$
H^{S}=\frac{\left(\lambda_{1, j} m_{11}+\lambda_{2, j} m_{21}\right)^{2}}{\left(\lambda_{1, j} m_{11}+\lambda_{2, j} m_{21}\right)^{2}+\left(\lambda_{2, j} m_{22}\right)^{2}},
$$

where $\lambda_{j}$ s are the error correction coefficients for country $j$. Different from the permanent factor in $G G_{j}$, Hasbrouck's approach can take into account the case of correlated innovations by providing upper and lower bounds on the information shares of each market. ${ }^{8}$

Note that neither indicator, GG factor or Hasbrouck information share, constitutes a formal causality test. Nonetheless, both appear to be intuitively informative for our question. We estimate these indicators country by country. Because the two indicators are distinct, they may or may not

\footnotetext{
${ }^{8}$ The upper and lower bounds on information shares of each market are calculated by estimating the vector errorcorrection models separately with sovereign spread and corporate spread as the first variable. This permits examination of alternative factor rotations for the innovations that either minimize or maximize the contribution of an innovation. See Hasbrouck (2003) for details.
} 
be consistent with each other. We will regard cases in which these two indicators agree with each other as particularly informative.

We first estimate the vector error-correction models for daily sovereign and corporate CDS portfolios of the thirty countries in our sample. The lag length is determined via Bayesian information criterion (BIC). We report the values of the estimated Hasbrouck's information shares (lower, upper bound and mid point value) and the permanent factor $G G_{j}$ in Table 5. (The estimates of the error correction models are omitted to save space.) We sort the results according to country groups classifed by institution quality as per Table 2 . As a reminder, countries that all available measures indicate strong property rights protection are assigned to Group 1; countries that all available measures indicate relatively weak property rights protection are assigned to Group 2 . As a residual, countries whose strength of property rights is difficult to tell due to mixed reports from different indicators are collected in Group 3. Our discussion below will be mainly based on comparing countries in the first two groups.

We report the estimates of the Hasbrouck information share (lower and upper bounds and the mid-point) and the GG permanent factor in Table 5. For some countries, the Hasbrouck measure indicates that the sovereign market accounts for a relatively small share of the new information reflected in the corporate CDS spreads, and the GG measure indicates that the sovereign CDS market has a relatively small permanent factor. In such cases, the messages from the two measures are consistent with each other, and both suggest that the sovereign CDS spreads are not an important driver for corporate CDS spreads. For other countries, both indicators suggest that the sovereign risks are an important driver for corporate spreads in these countries. It is striking that most countries that belong to the group with strong property rights institutions (i.e., Group 1), such as Finland, Japan, the United Kingdom, and the United States, are in the former category (less transfer risks from sovereigns to corporates). In comparison, most countries with weak institutions (Group 2), such as China, Kazakhstan, and the Philippines, are in the latter category (more transfer risks). 
To further evaluate the impact of sovereign spread on the price discovery of corporate risks, we calculate the cumulative impulse response function (IRF) from the vector error-correction models. In particular, the response function for a given country represents the long-run impact of a shock in the sovereign credit market on the pricing in the corporate credit market. The IRFs for countries with strong property rights institutions are plotted in Figure 3, whereas those for weak institution countries are in Figure 4. (We ignore countries where institutional strength is difficult to assess.) A comparison of these two groups of IRFs reveals a striking difference. Generally speaking, the impulse responses of the corporate CDS spreads in countries with strong institutions to an innovation in the sovereign spread are weak, if existing at all. In comparison, the opposite is true for the corporate CDS responses in countries with weak institutions.

\subsection{Additional Checks}

The results so far strongly suggest a sovereign 'grabbing-hand' risk embedded in corporate credit risks but only in countries with weak property rights institutions. To bolster confidence in our preferred interpretation, we conduct a series of additional robustness checks.

Our first check allows for a potentially special role by two types of firms. First, the fate of state-owned firms may have a "natural" connection with the fate of the state. If the sovereign government is in a fiscal crisis, the funds at the state-owned firms could be sucked to plug the government's fiscal hole. Second, financial institutions (large banks in particular) are also special. Governments around the world appear more inclined to treat a bank failure as a "systematic" risk than the failure of a non-financial entity, and therefore are more likely to extend its fiscal capacity to save failing financial institutions. Therefore, one concern about the main results of the paper is that the connection between sovereign and corporate risks may be artificially driven by including banks and state-owned firms in the sample. As a (conservative) robustness check, we now look at a narrower sample that excludes the 141 state-owned firms (including state-owned financial firms) 
and the 638 non-state-owned financial firms from a total of 2745 firms. The results are reported in Table 6. Compared to the previous results in Table 4, the same qualitative features are preserved. In particular, property rights institutions (as measured by either the index on the constraints on the executive branch or the index on the control of expropriation risks) weaken the association between corporate and sovereign CDS spreads, whereas the contracting institutions (as measured by the creditor rights index and the number of days needed to enforce a contract) do not have a significant impact.

Our second check allows for a potentially special role of the United States, which is the largest single-country source for firms in our sample, with 1314 firms out of a total of 2745 firms. To see if the U.S. firms have an undue influence on the final result, we exclude them altogether from the sample and report the regression results in Table 7. As one can see, this does not make a material difference either. Instead, excluding American firms strengthens our results that property rights institutions become more significant.

A third robustness check is to include control variables that capture market-wide changes that affect both corporate and sovereign risk directly. Our market-wide controls are the country-level stock market returns (based on the MSCI country indices) and the global stock market return (using the MSCI global equity market index). As shown in Table 8, we find that the coefficients on sovereign CDS are essentially unchanged and remain highly statistically significant. Such results indicate that countries with more restrictions on expropriation risks tend to have a lower 'grabbinghand' risk from the sovereign to the corporate sector.

Finally, we examine if a lag structure of sovereign CDS spreads would make a difference. In particular, in addition to the contemporaneous change in the country-level CDS spread, we include changes in the the sovereign spread 5, 10, and 20 days earlier. The results are reported in Table 9. This turns out to make no difference either. None of the lagged country-level CDS spread changes is statistically significant. The contemporaneous country-level CDS spread is still 
a positive predictor of the company-level CDS spreads for firms in the same country. Most importantly, better property rights protection at the country level significantly reduces the association between sovereign and corporate CDS spreads, while the contracting institutions do not have the same effect.

\section{Concluding Remarks}

We use a novel international CDS data set to study the "transfer risk" from the government to the corporate sector and the potential role of institutions in mitigating the risk. We find sovereign credit risk on average has a statistically and economically significant influence on corporate credit risks. Such a sovereign-corporate relation varies across types of firms. For example, state-owned companies tend to have a stronger sovereign-corporate relation. However, not all governments have an equal ability to expropriate the private sector. In particular, the "transfer risks" are more subdue and constrained in countries with stronger property rights institutions.

Our findings point to a concrete channel for understanding why the country factor is more important for asset returns in some countries than others. This has potentially important implications for thinking about effective ways to share risks internationally and about cross country variations in the determinants of asset pricing and international capital flows. We leave a systematic investigation of these issues for future research. 


\section{References}

[1] Acemoglu, Daron, and Simon Johnson, 2005, Unbundling Institutions, Journal of Political Economy, 113(5), 949-995.

[2] Acharya, Viral, I. Drechsler, and Philip Schnabl, 2011, A Pyrrhic Victory? Bank Bailouts and Sovereign Credit Risk. NBER Working Paper No. 17136.

[3] Alter, Adrian, and Yves Schueler, 2011, Credit Spread Interdependencies of European States and Banks during the Financial Crisis", Working Paper.

[4] Attinasi, Maria-Grazia, Cristina Checherita and Christiane Nickel, 2009, What Explains the Surge in Euro Area Sovereign Spreads during the Financial Crisis of 2007-09?”, European Central Bank Working Paper No. 1131.

[5] Baillie, R., G. Booth, Y. Tse, and T. Zabotina, 2002, Price Discovery and Common Factor Models, Journal of Financial Markets 5, 309-21.

[6] Bernoth, Kerstin, Jurgen von Hagen, and Ludger Schuknecht, 2006, Sovereign Risk Premiums in the European Government Bond Market, Working Paper.

[7] Blanco, Roberto, Simon Brennan, and Ian W. Marsh, 2005, An Empirical Analysis of the Dynamic Relation between Investment-grade Bonds and Credit Default Swaps. Journal of Finance, 60, 2255-2281.

[8] Bongaerts, Dion, Frank De Jong, and Joost Driessen, 2011, Derivative Pricing with Liquidity Risk: Theory and Evidence from the Credit Default Swap Market, Journal of Finance, 66, 203-240.

[9] Collin-Dufresne, Pierre, Robert S. Goldstein, J. Spencer Martin, 2001, The Determinants of Credit Spread Changes, Journal of Finance, 56, 2177-2207. 
[10] Dieckmann, Stephan and Thomas Plank, 2011, Default Risk of Advanced Economies: An Empirical Analysis of Credit Default Swaps during the Financial Crisis", Working Paper, Wharton School of Business, University of Pennsylvania.

[11] Dittmar, Robert, and Kathy Yuan, 2008, Do Sovereign Bonds Benefit Corporate Bonds in Emerging Markets?, Review of Financial Studies, volume 21, 1983-2014.

[12] Djankov, Simeon, Rafael La Porta, Florencio Lopez-de-Silanes, and Andrei Shleifer, 2003, Courts, Quarterly Journal of Economics, 118, 453-517.

[13] Djankov, Simeon, Caralee McLiesh and Andrei Shleifer, 2007, Private Credit in 129 Countries, Journal of Financial Economics, 84 (2), 299-329.

[14] Durbin, Erik, and David Ng, 2005, The Sovereign Ceiling and Emerging Market Corporate Bond Spreads, Journal of International Money and Finance, 24, 631-649.

[15] Ejsing, Jacob and Wolfgang Lemke, 2011, The Janus-headed salvation: Sovereign and bank credit risk premia during 2008-2009," Economics Letters, 110, 28 - 31.

[16] Gurr, Ted Robert, 1997, Polity II: Political Structures and Regime Change, 1800, Unpublished manuscript, University of Colorado.

[17] Hilscher, Jens, and Nosbusch Yves, 2010, Determinants of Sovereign Risk: Macroeconomic Fundamentals and the Pricing of Sovereign Debt, Review of Finance, 14(2), 235-262.

[18] La Porta, Rafael, Florencio Lopez-de-Silanes, Andrei Shleifer, and Robert Vishny, 1997, Legal Determinants of External Finance, Journal of Finance, 52, 1131-1150.

[19] La Porta, Rafael, Florencio Lopez-de-Silanes, Andrei Shleifer, and Robert Vishny, 1998, Law and Finance, Journal of Political Economy, 106, 1113-1155.

[20] La Porta, Rafael, Florencio Lopez-de-Silanes, Andrei Shleifer, and Robert Vishny, 2000, Investor Protection and Corporate Governance, Journal of Financial Economics, 58, 3-27. 
[21] Longstaff, Francis, Jun Pan, Lasse H Pedersen, and Ken Singleton, 2010, How Sovereign is Sovereign Credit Risk? forthcoming, American Economic Journal: Macroeconomics.

[22] Mulligan, Casey, and Andrei Shleifer, 2005, The Extent of the Market and the Supply of Regulation, Quarterly Journal of Economics, 120, 1445-1474.

[23] Pagano, Marco, and Tullio Jappelli, 1993, Information Sharing in Credit Markets, Journal of Finance, 43, 1693-1718.

[24] Peter, Marcel, and Martin Grandes, 2005, How Important Is Sovereign Risk in Determining Corporate Default Premia? The Case of South Africa, International Monetary Fund, working Paper.

[25] Reinhart, Carmen, and Kenneth Rogoff, 2009, The Forgotten History of Domestic Debt, Working paper.

[26] Stulz Rene, 2010, Credit Default Swaps and the Credit Crisis, Journal of Economic Perspectives, Vol. 24, No. 1, 73-92.

[27] Yuan, Kathy, 2005, The Liquidity Service of Benchmark Securities, Journal of European Economic Association, 3, 11561180. 


\section{Table 1: Summary Statistics of International Credit Default Swap Spreads (in bps)}

For each country, Panel A reports the number of firm-day observations, the number of reference entities, the mean, median and standard deviation of five-year corporate as well as sovereign CDS spreads. Panel B reports the number of reference entities by industry sector across four regions: Asia, Europe, North America, and other areas. The sample period is from January 1, 2008 to February 10, 2010.

\begin{tabular}{|c|c|c|c|c|c|c|c|c|}
\hline \multicolumn{9}{|c|}{ Panel A: By Country } \\
\hline \multirow[b]{2}{*}{ Country } & \multirow[b]{2}{*}{ Obs. } & \multirow[b]{2}{*}{ Firms } & \multicolumn{3}{|c|}{ Corporate CDS } & \multicolumn{3}{|c|}{ Sovereign CDS } \\
\hline & & & Mean & Median & Std & Mean & Median & Std \\
\hline Austria & 6289 & 18 & 157 & 112 & 178 & 71 & 71 & 56 \\
\hline Belgium & 5459 & 13 & 137 & 87 & 113 & 49 & 40 & 32 \\
\hline Brazil & 11835 & 34 & 337 & 248 & 260 & 198 & 146 & 101 \\
\hline Chile & 3896 & 12 & 224 & 203 & 116 & 114 & 74 & 71 \\
\hline China & 4026 & 9 & 189 & 137 & 122 & 100 & 77 & 57 \\
\hline Denmark & 5623 & 14 & 336 & 254 & 269 & 42 & 32 & 38 \\
\hline Finland & 5476 & 12 & 199 & 114 & 164 & 28 & 25 & 20 \\
\hline France & 42850 & 91 & 195 & 115 & 214 & 31 & 27 & 21 \\
\hline Germany & 45095 & 109 & 267 & 117 & 533 & 26 & 23 & 20 \\
\hline Greece & 4368 & 8 & 220 & 169 & 152 & 138 & 124 & 89 \\
\hline Hong Kong & 16424 & 35 & 203 & 131 & 182 & 68 & 57 & 32 \\
\hline Indonesia & 4083 & 12 & 556 & 375 & 438 & 359 & 259 & 204 \\
\hline Ireland & 7423 & 20 & 348 & 275 & 217 & 127 & 140 & 94 \\
\hline Italy & 21456 & 51 & 171 & 93 & 266 & 84 & 75 & 48 \\
\hline Japan & 204166 & 431 & 159 & 74 & 385 & 42 & 40 & 25 \\
\hline Kazakhstan & 4247 & 12 & 1422 & 1004 & 1184 & 462 & 272 & 326 \\
\hline Korea & 22251 & 46 & 271 & 184 & 265 & 179 & 122 & 121 \\
\hline Malaysia & 7370 & 16 & 173 & 135 & 104 & 138 & 105 & 75 \\
\hline Mexico & 6977 & 25 & 419 & 296 & 407 & 190 & 146 & 102 \\
\hline Netherlands & 32272 & 82 & 181 & 99 & 265 & 38 & 31 & 32 \\
\hline Norway & 5252 & 14 & 191 & 83 & 310 & 20 & 17 & 14 \\
\hline Philippines & 5209 & 13 & 305 & 257 & 157 & 264 & 232 & 103 \\
\hline Portugal & 4409 & 8 & 124 & 113 & 56 & 69 & 60 & 38 \\
\hline Russian Federation & 10790 & 23 & 660 & 450 & 511 & 310 & 201 & 236 \\
\hline South Africa & 4284 & 13 & 552 & 509 & 345 & 236 & 187 & 115 \\
\hline Spain & 15222 & 31 & 232 & 144 & 259 & 74 & 71 & 37 \\
\hline Sweden & 15363 & 34 & 170 & 102 & 188 & 50 & 49 & 40 \\
\hline Thailand & 6936 & 17 & 367 & 152 & 459 & 139 & 113 & 70 \\
\hline United Kingdom & 96194 & 229 & 210 & 115 & 287 & 58 & 56 & 41 \\
\hline United States & 551214 & 1314 & 341 & 155 & 581 & 31 & 28 & 21 \\
\hline Total & 1176459 & 2745 & 311 & 210 & 299 & 124 & 97 & 76 \\
\hline
\end{tabular}




\begin{tabular}{lccccc}
\hline \multicolumn{5}{c}{ Panel B: By Sector } \\
\\
Sector & Asia & Europe & America & Others & All \\
\hline Financials & 119 & 260 & 248 & 11 & 638 \\
Government & 69 & 34 & 60 & 8 & 171 \\
Industrials & 97 & 96 & 152 & 5 & 350 \\
Basic Materials & 51 & 40 & 76 & 17 & 184 \\
Consumer Goods & 86 & 72 & 138 & 9 & 305 \\
Consumer Services & 57 & 98 & 210 & 12 & 377 \\
Health Care & 8 & 15 & 86 & 0 & 109 \\
Oil \& Gas & 13 & 24 & 92 & 2 & 131 \\
Technology & 36 & 13 & 66 & 0 & 115 \\
Telecommunications & 18 & 38 & 48 & 10 & 114 \\
Utilities & 25 & 79 & 138 & 9 & 251 \\
\hline Total & 579 & 769 & 1314 & 83 & 2745 \\
\hline
\end{tabular}


Table 2: Summary Statistics of Institutional Measures

Panel A

\begin{tabular}{|c|c|c|c|c|c|c|}
\hline & & $\begin{array}{l}\text { Constraint on } \\
\text { Executive }\end{array}$ & $\begin{array}{c}\text { Risk of } \\
\text { Expropriation }\end{array}$ & $\begin{array}{c}\text { Rule of } \\
\text { Law }\end{array}$ & $\begin{array}{l}\text { Credit Right } \\
\text { Index }\end{array}$ & $\begin{array}{c}\text { Contract } \\
\text { Enforcement Days }\end{array}$ \\
\hline \multirow{11}{*}{ Group 1} & Austria & 7.00 & 9.69 & 1.84 & 3 & 374 \\
\hline & Belgium & 7.00 & 9.63 & 1.42 & 2 & 112 \\
\hline & Denmark & 7.00 & 9.67 & 1.92 & 3 & 83 \\
\hline & Finland & 7.00 & 9.67 & 1.91 & 1 & 240 \\
\hline & Germany & 7.00 & 9.90 & 1.69 & 3 & 184 \\
\hline & Ireland & 7.00 & 9.67 & 1.62 & 1 & 217 \\
\hline & Japan & 7.00 & 9.67 & 1.32 & 2 & 60 \\
\hline & Netherlands & 7.00 & 9.98 & 1.73 & 3 & 48 \\
\hline & Norway & 7.00 & 9.88 & 1.93 & 2 & 87 \\
\hline & United Kingdom & 7.00 & 9.71 & 1.67 & 4 & 288 \\
\hline & United States & 7.00 & 9.98 & 1.55 & 1 & 250 \\
\hline \multirow{10}{*}{ Group 2} & Brazil & 6.00 & 7.62 & -0.35 & 1 & 566 \\
\hline & China & 3.00 & & -0.41 & 2 & 241 \\
\hline & Indonesia & 6.00 & 7.16 & -0.81 & 2 & 570 \\
\hline & Kazakhstan & 2.00 & & -0.90 & 2 & 400 \\
\hline & Korea & 6.00 & 8.31 & 0.80 & 3 & 75 \\
\hline & Malaysia & 4.11 & 7.95 & 0.49 & 3 & 300 \\
\hline & Mexico & 6.00 & 7.29 & -0.45 & 0 & 421 \\
\hline & Philippines & 6.00 & 5.22 & -0.51 & 1 & 380 \\
\hline & Russia & 4.78 & & -0.92 & 2 & 330 \\
\hline & hailand & 6.00 & 7.42 & 0.11 & 2 & 390 \\
\hline \multirow{12}{*}{ Group 3} & Chile & 7.00 & 7.50 & 1.22 & 2 & 305 \\
\hline & France & 6.00 & 9.65 & 1.37 & 0 & 75 \\
\hline & Greece & 7.00 & 7.12 & 0.78 & 1 & 151 \\
\hline & Hong Kong & & 8.29 & 1.35 & 4 & 211 \\
\hline & Italy & 7.00 & 9.35 & 0.60 & 2 & 1390 \\
\hline & Portugal & 7.00 & 8.90 & 1.11 & 1 & 320 \\
\hline & South Africa & 7.00 & 6.88 & 0.12 & 3 & 277 \\
\hline & Spain & 7.00 & 9.52 & 1.18 & 2 & 169 \\
\hline & Sweden & 7.00 & 9.40 & 1.86 & 1 & 208 \\
\hline & Median & 7 & 9.38 & 1.27 & 2 & 245.5 \\
\hline & Mean & 6.17 & 8.78 & 0.92 & 1.97 & 291.75 \\
\hline & Std Err. & 1.43 & 1.23 & 0.94 & 1.00 & 240.17 \\
\hline
\end{tabular}




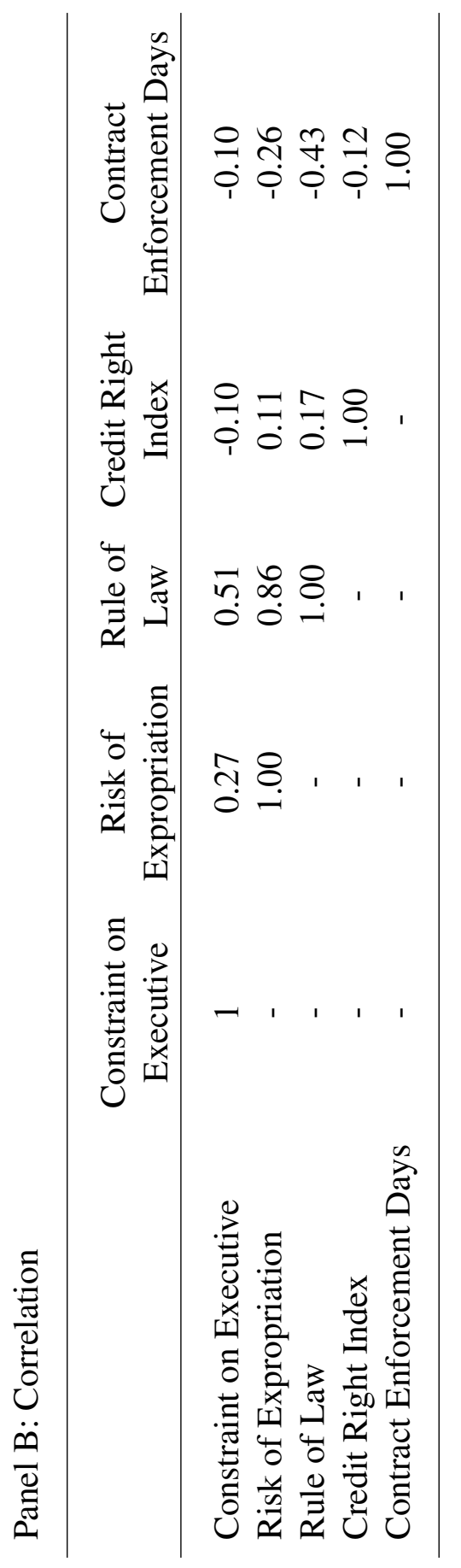

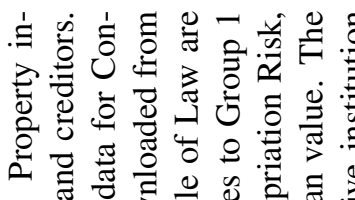

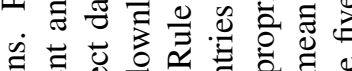

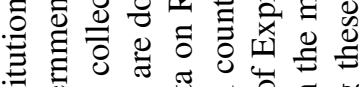

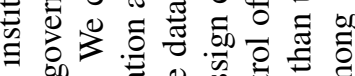
60 00 .

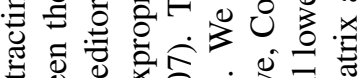

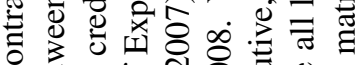
०

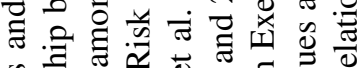

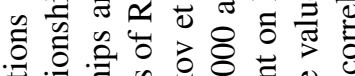

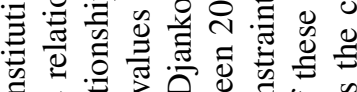
至

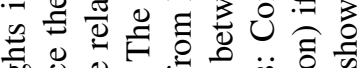

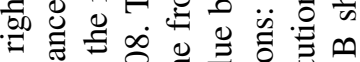

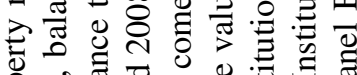

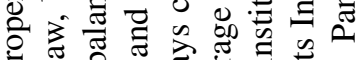
흥

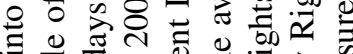
政呵

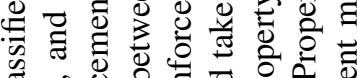

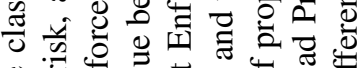

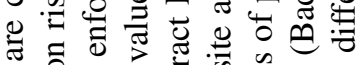

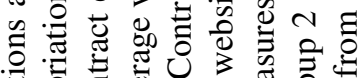

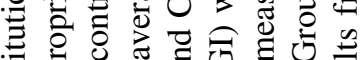

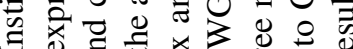
的的

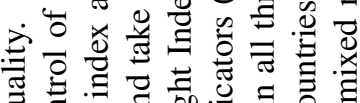
б 하의

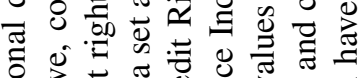

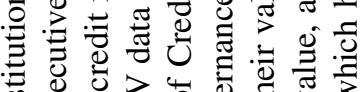

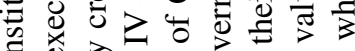
:

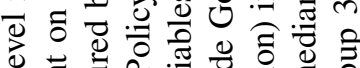
․ㅡㄹ

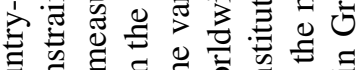

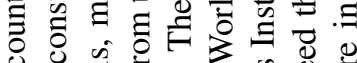

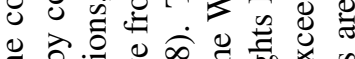
定.

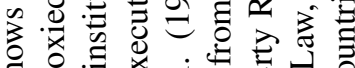

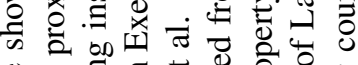

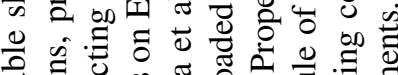

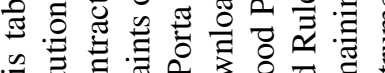

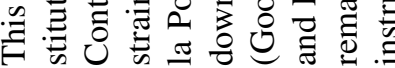




\section{Table 3: Average Sovereign-Corporate Credit Risk Relationship across Countries}

Panel regression results with clustered standard errors in parentheses. Sector dummy variables indicate whether a reference entity belongs to one of four sectors: local government, state-owned non- financial, state-owned financial, and non-state-owned financial sector. Emerging-Mkt is a dummy variable indicating if a country belongs to the emerging market according to a joint consideration of MSCI and Dow Jones list. Regression coefficients that are statistical significant at the 5 percent level are in bold script. The sample period is from January 2008 to February 2010 .

Dependent variable : $\Delta \mathrm{CDS}$ (firm)

\begin{tabular}{|c|c|c|c|c|c|c|c|}
\hline & (1) & (2) & (3) & (4) & (5) & (6) & (7) \\
\hline$\Delta \mathrm{CDS}$ (country) & $\begin{array}{c}\mathbf{0 . 7 1} \\
(0.07)\end{array}$ & $\begin{array}{c}\mathbf{0 . 6 7} \\
(0.06)\end{array}$ & $\begin{array}{c}\mathbf{0 . 5 9} \\
(0.15)\end{array}$ & $\begin{array}{c}\mathbf{0 . 7 7} \\
(0.14)\end{array}$ & $\begin{array}{c}\mathbf{0 . 7 2} \\
(0.15)\end{array}$ & $\begin{array}{c}\mathbf{0 . 6 8} \\
(0.07)\end{array}$ & $\begin{array}{c}\mathbf{0 . 6 5} \\
(0.06)\end{array}$ \\
\hline Local Government x $\Delta \mathrm{CDS}$ (country) & & $\begin{array}{c}0.02 \\
(0.16)\end{array}$ & & & $\begin{array}{c}0.12 \\
(0.21)\end{array}$ & & $\begin{array}{c}0.02 \\
(0.15)\end{array}$ \\
\hline State Non-Financial x $\Delta \mathrm{CDS}$ (country) & & $\begin{array}{c}\mathbf{0 . 1 7} \\
(0.08)\end{array}$ & & & $\begin{array}{c}\mathbf{0 . 2 7} \\
(0.11)\end{array}$ & & $\begin{array}{c}\mathbf{0 . 1 7} \\
(0.08)\end{array}$ \\
\hline State-owned Financial x $\Delta \mathrm{CDS}$ (country) & & $\begin{array}{c}0.30 \\
(0.20)\end{array}$ & & & $\begin{array}{c}\mathbf{0 . 3 9} \\
(0.19)\end{array}$ & & $\begin{array}{c}\mathbf{0 . 3 0} \\
(0.18)\end{array}$ \\
\hline Non-Gov Financial x $\Delta$ CDS(country) & & $\begin{array}{c}0.00 \\
(0.11)\end{array}$ & & & $\begin{array}{c}-0.09 \\
(0.07)\end{array}$ & & $\begin{array}{l}-0.00 \\
(0.11)\end{array}$ \\
\hline $\operatorname{lag}(\operatorname{CDS}($ Firm $))$ x $\Delta \operatorname{CDS}$ (country)/100 & & & $\begin{array}{c}0.01 \\
(0.02)\end{array}$ & & $\begin{array}{c}0.03 \\
(0.03)\end{array}$ & & \\
\hline $\operatorname{lag}(\operatorname{CDS}($ Country $))$ x $\Delta \mathrm{CDS}($ country $) / 100$ & & & & $\begin{array}{l}-0.01 \\
(0.04)\end{array}$ & $\begin{array}{l}-0.07 \\
(0.04)\end{array}$ & & \\
\hline Emerging-Mkt x $\Delta \mathrm{CDS}$ (country) & & & & & & $\begin{array}{c}0.04 \\
(0.12)\end{array}$ & $\begin{array}{c}0.02 \\
(0.10)\end{array}$ \\
\hline Constant & $\begin{array}{c}0.87 \\
(0.16)\end{array}$ & $\begin{array}{c}0.89 \\
(0.15)\end{array}$ & $\begin{array}{c}0.91 \\
(0.14)\end{array}$ & $\begin{array}{c}0.85 \\
(0.18)\end{array}$ & $\begin{array}{c}0.86 \\
(0.18)\end{array}$ & $\begin{array}{c}0.89 \\
(0.17)\end{array}$ & $\begin{array}{c}0.90 \\
(0.16)\end{array}$ \\
\hline Time Fixed Effect & Yes & Yes & Yes & Yes & Yes & Yes & Yes \\
\hline Country Fixed Effect & Yes & Yes & Yes & Yes & Yes & Yes & Yes \\
\hline Number of Obs.(in million) & 1.18 & 1.18 & 1.18 & 1.18 & 1.18 & 1.18 & 1.18 \\
\hline Adjusted R-square & 0.01 & 0.01 & 0.01 & 0.01 & 0.01 & 0.01 & 0.01 \\
\hline
\end{tabular}




\section{Table 4: The Role of Institutions in the Sovereign- Corporate Credit Risk Relationship}

Panel regression results with clustered standard errors in parentheses. Regression coefficients with statistical significance at the 5 percent level or above are in bold script. Each institution instrument is grouped into three quantiles except Constraint on executive, which is grouped into two quantiles for concentrating distribution. Each country is assigned to corresponding quantile under every instrument. Throughout all institution instruments, Q1 is dummy variable referring to the smallest quantile which indicates lower quality of institutions. The sample period is from January 2008 to February 2010.

Panel A: Property Rights Institutions

\begin{tabular}{|c|c|c|c|}
\hline \multicolumn{4}{|c|}{ Dependent variable : $\Delta \mathrm{CDS}$ (firm) } \\
\hline & (1) & (2) & (3) \\
\hline$\Delta \mathrm{CDS}$ (country) & $\begin{array}{c}\mathbf{0 . 7 9} \\
(0.08)\end{array}$ & $\begin{array}{c}\mathbf{0 . 7 7} \\
(0.07)\end{array}$ & $\begin{array}{c}\mathbf{0 . 7 7} \\
(0.08)\end{array}$ \\
\hline $\begin{array}{c}\text { Constraint on Executive } \\
\text { Q2 } x \Delta \operatorname{CDS} \text { (country) }\end{array}$ & $\begin{array}{l}\mathbf{- 0 . 2 5} \\
(0.11)\end{array}$ & & \\
\hline $\begin{array}{l}\text { Control of Expropriation } \\
\text { Q2 x } \Delta \mathrm{CDS} \text { (country) }\end{array}$ & & $\begin{array}{l}-0.02 \\
(0.08)\end{array}$ & \\
\hline Q3 x $\Delta$ CDS(country) & & $\begin{array}{l}\mathbf{- 0 . 3 0} \\
(0.10)\end{array}$ & \\
\hline $\begin{array}{l}\text { Rule of Law } \\
\text { Q2 x } \Delta \text { CDS(country) }\end{array}$ & & & $\begin{array}{l}-0.09 \\
(0.11)\end{array}$ \\
\hline Q3 x $\Delta$ CDS(country) & & & $\begin{array}{l}-0.18 \\
(0.10)\end{array}$ \\
\hline Constant & $\begin{array}{c}0.94 \\
(0.15) \\
\end{array}$ & $\begin{array}{c}0.87 \\
(0.16) \\
\end{array}$ & $\begin{array}{c}0.89 \\
(0.17) \\
\end{array}$ \\
\hline Time FE & Yes & Yes & Yes \\
\hline Country FE & Yes & Yes & Yes \\
\hline Number of obs. & 1176459 & 1176459 & 1176459 \\
\hline Adj.R-square & 0.01 & 0.01 & 0.01 \\
\hline
\end{tabular}


Panel B: Contracting Institutions

\begin{tabular}{lcc}
\hline \multicolumn{3}{c}{ Dependent variable : $\Delta$ CDS(firm) } \\
\hline & $(1)$ & $(2)$ \\
\hline$\Delta$ CDS(country) & $\mathbf{0 . 7 1}$ & $\mathbf{0 . 6 7}$ \\
& $(0.05)$ & $(0.10)$ \\
Credit Right Index & & \\
Q2 x $\Delta$ CDS(country) & 0.06 & \\
& $(0.12)$ & \\
Q3 x $\Delta$ CDS(country) & -0.03 & \\
& $(0.10)$ & \\
Contract Enforcement Days & & \\
Q2 x $\Delta$ CDS(country) & & -0.03 \\
& & $(0.16)$ \\
Q3 x $\Delta$ CDS(country) & & 0.12 \\
& & $(0.12)$ \\
Constant & 0.89 & 0.90 \\
& $(0.16)$ & $(0.17)$ \\
\hline Time FE & Yes & Yes \\
Country FE & Yes & Yes \\
Number of Obs & 1176459 & 1176459 \\
Adjusted R-square & 0.01 & 0.01 \\
\hline
\end{tabular}




\section{Table 5: Relative Contributions to Price Discovery}

This table reports the contributions to the credit price discovery process made by sovereign CDS and corporate CDS within a country. The measures are based on the vector error correction model as

$$
\begin{aligned}
\Delta \ln (C D S)_{j, t}^{S} & =\lambda_{1, j}\left(\ln (C D S)_{j, t-1}^{S}-\alpha_{0, j}-\alpha_{1, j} \ln (C D S)_{j, t-1}^{C}\right)+\sum_{i=1}^{p} \beta_{1, j, i} \Delta \ln (C D S)_{j, t-i}^{S}+\sum_{i=1}^{p} \delta_{1, j, i} \Delta \ln (C D S)_{t-i}^{C}+\varepsilon_{1, j, t} \\
\Delta \ln (C D S)_{j, t}^{C} & =\lambda_{2, j}\left(\ln (C D S)_{j, t-1}^{S}-\alpha_{0, j}-\alpha_{1, j} \ln (C D S)_{j, t-1}^{C}\right)+\sum_{i=1}^{p} \beta_{2, j, i} \Delta \ln (C D S)_{j, t-i}^{S}+\sum_{i=1}^{p} \delta_{2, j, i} \Delta \ln (C D S)_{j, t-i}^{C}+\varepsilon_{2, j, t} .
\end{aligned}
$$

We use two measures: (1) Hasbrouck Information Share range, its lower and upper bound as well as mid point of this range; (2) the Granger- Gonzalo measure. Both measures indicate the price discovery contribution made by the sovereign CDS in a country. We report the results by country group as defined in Table 2 . The sample period is from

\begin{tabular}{|c|c|c|c|c|c|}
\hline & & \multicolumn{3}{|c|}{ Hasbrouck } & \multirow[b]{2}{*}{ GG } \\
\hline & & Lower & Upper & Mid & \\
\hline Group 1 & Austria & 0.12 & 0.71 & 0.42 & 0.15 \\
\hline \multirow[t]{10}{*}{ (Strong Property Rights) } & Belgium & 0.33 & 0.46 & 0.40 & -0.12 \\
\hline & Denmark & 0.48 & 0.88 & 0.68 & -0.45 \\
\hline & Finland & 0.40 & 0.90 & 0.65 & -1.28 \\
\hline & Germany & 0.61 & 0.93 & 0.77 & -0.51 \\
\hline & Ireland & 0.09 & 0.49 & 0.29 & -0.22 \\
\hline & Japan & 0.02 & 0.33 & 0.18 & -1.20 \\
\hline & Netherlands & 0.22 & 0.80 & 0.51 & -0.35 \\
\hline & Norway & 0.63 & 0.92 & 0.77 & -0.72 \\
\hline & United Kingdom & 0.02 & 0.52 & 0.27 & -0.35 \\
\hline & United States & 0.16 & 0.98 & 0.57 & -0.19 \\
\hline Group 2 & Brazil & 0.94 & 0.98 & 0.96 & 0.62 \\
\hline \multirow[t]{9}{*}{ (Weak Property Rights) } & China & 1.00 & 1.00 & 1.00 & 0.90 \\
\hline & Indonesia & 0.96 & 0.99 & 0.98 & 1.16 \\
\hline & Kazakhstan & 0.99 & 0.99 & 0.99 & 1.75 \\
\hline & Korea & 1.00 & 0.99 & 0.99 & 0.31 \\
\hline & Malaysia & 0.79 & 0.92 & 0.86 & 0.50 \\
\hline & Mexico & 0.96 & 0.99 & 0.97 & 0.71 \\
\hline & Philippines & 1.00 & 1.00 & 1.00 & 1.00 \\
\hline & Russia & 0.62 & 0.92 & 0.77 & 0.35 \\
\hline & Thailand & 0.93 & 0.97 & 0.95 & 0.65 \\
\hline Group 3 & Chile & 0.21 & 0.64 & 0.42 & -0.30 \\
\hline \multirow[t]{8}{*}{ (Conflicting Classifications) } & France & 0.32 & 0.92 & 0.62 & -0.56 \\
\hline & Greece & 0.02 & 0.04 & 0.03 & -0.77 \\
\hline & Hong Kong & 0.01 & 0.13 & 0.07 & -0.48 \\
\hline & Italy & 0.06 & 0.22 & 0.14 & -0.74 \\
\hline & Portugal & 0.07 & 0.22 & 0.15 & -0.27 \\
\hline & South Africa & 0.89 & 0.89 & 0.89 & 0.38 \\
\hline & Spain & 0.23 & 0.54 & 0.39 & -1.03 \\
\hline & Sweden & 0.14 & 0.54 & 0.34 & -0.55 \\
\hline
\end{tabular}
January 1, 2008 to February 10, 2010. 


\section{Table 6: Excluding State-Owned Firms and Financial Sector from the Sample}

Panel regression results with clustered standard errors in parentheses. Regression coefficients that are statistical significant at the 5 percent level are in bold script. Each institutional instrument (except constraint on executive) is grouped into three terciles. Each country is assigned to corresponding tercile under every instrument. Constraint on executive is divided into two halves due to clustered values. Throughout all institutional instruments, Q1 is the dummy variable referring to the smallest tercile which indicates lower quality of institutions. The higher tercile suggests a lower degree of transfer risk from sovereign risk to corporate credit risk. The sample excludes all reference entities in the government or financial sectors. The sample period is from January 2008 to February 2010.

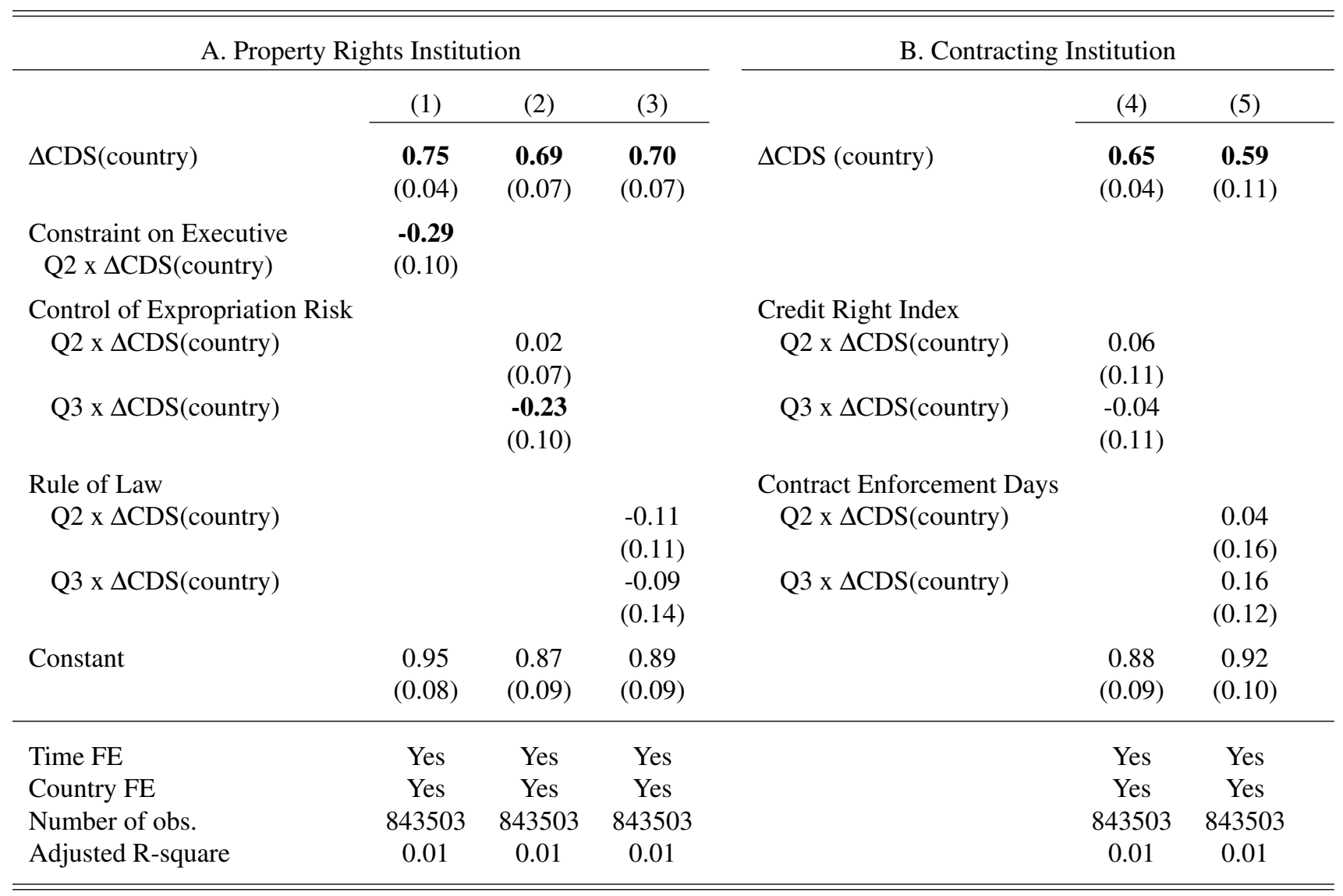




\section{Table 7: Excluding the U.S Firms from the Sample}

Panel regression results with clustered standard errors in parentheses. Regression coefficients that are statistical significant at the 5 percent level are in bold script.

\begin{tabular}{|c|c|c|c|c|c|c|}
\hline \multicolumn{4}{|c|}{ A. Property Rights Institution } & \multicolumn{3}{|c|}{ B. Contracting Institution } \\
\hline & (1) & (2) & (3) & & (4) & (5) \\
\hline$\Delta \mathrm{CDS}$ (country) & $\begin{array}{c}\mathbf{0 . 7 9} \\
(0.06)\end{array}$ & $\begin{array}{c}\mathbf{0 . 7 6} \\
(0.08)\end{array}$ & $\begin{array}{c}\mathbf{0 . 7 7} \\
(0.08)\end{array}$ & $\Delta \mathrm{CDS}$ (country) & $\begin{array}{c}\mathbf{0 . 6 6} \\
(0.05)\end{array}$ & $\begin{array}{c}\mathbf{0 . 6 8} \\
(0.09)\end{array}$ \\
\hline $\begin{array}{c}\text { Constraint on Executive } \\
\text { Q2 } x \Delta \text { CDS (country) }\end{array}$ & $\begin{array}{l}\mathbf{- 0 . 3 8} \\
(0.08)\end{array}$ & & & & & \\
\hline Control of Expropriation Risk & & & & Credit Right Index & & \\
\hline Q2 x $\Delta \mathrm{CDS}$ (country) & & $\begin{array}{l}-0.01 \\
(0.09)\end{array}$ & & Q2 x $\Delta \mathrm{CDS}$ (country) & $\begin{array}{l}0.12 \\
(0.11)\end{array}$ & \\
\hline Q3 x $\triangle \mathrm{CDS}$ (country) & & $\begin{array}{l}\mathbf{- 0 . 2 7} \\
(0.11)\end{array}$ & & Q3 x $\Delta \mathrm{CDS}$ (country) & $\begin{array}{l}0.04 \\
(0.1)\end{array}$ & \\
\hline Rule of Law & & & & Contract Enforcement Days & & \\
\hline Q2 x $\Delta \mathrm{CDS}$ (country) & & & $\begin{array}{l}-0.13 \\
(0.13)\end{array}$ & Q2 x $\Delta \mathrm{CDS}$ (country) & & $\begin{array}{l}-0.16 \\
(0.15)\end{array}$ \\
\hline Q3 x $\Delta$ CDS(country) & & & $\begin{array}{l}-0.16 \\
(0.11)\end{array}$ & Q3 x $\Delta \mathrm{CDS}$ (country) & & $\begin{array}{c}0.11 \\
(0.12)\end{array}$ \\
\hline Constant & $\begin{array}{c}0.91 \\
(0.15)\end{array}$ & $\begin{array}{c}0.89 \\
(0.17)\end{array}$ & $\begin{array}{c}0.87 \\
(0.17)\end{array}$ & & $\begin{array}{c}0.84 \\
(0.19)\end{array}$ & $\begin{array}{c}0.90 \\
(0.17)\end{array}$ \\
\hline Time FE & Yes & Yes & Yes & & Yes & Yes \\
\hline Country FE & Yes & Yes & Yes & & Yes & Yes \\
\hline Number of obs. & 623748 & 623748 & 623748 & & 623748 & 623748 \\
\hline Adjusted R-square & 0.04 & 0.04 & 0.04 & & 0.04 & 0.04 \\
\hline
\end{tabular}




\section{Table 8: Controlling for Global and Country-level Economic Risk}

The table presents results of the following panel regression:

$$
\Delta C D S_{i, k, t}=\alpha_{i}+\delta_{t}+\beta_{0} \Delta C D S_{k, t}+\sum_{s} \beta_{s} \text { Inst }_{s, k} \cdot \Delta C D S_{k, t}+\gamma_{0} R_{k, t}+\gamma_{1} R_{g l o b a l, t}+\varepsilon_{i, k, t},
$$

where $R_{\text {global }}$ is the $\log$ return of MSCI world stock market index, $R_{k}$ is the country-level stock market return using MSCI country index. Standard deviation is reported in the parentheses. Regression coefficients that are statistical significant at the 5 percent level are in bold script. The sample period is from January 1, 2008 to February 10, 2010.

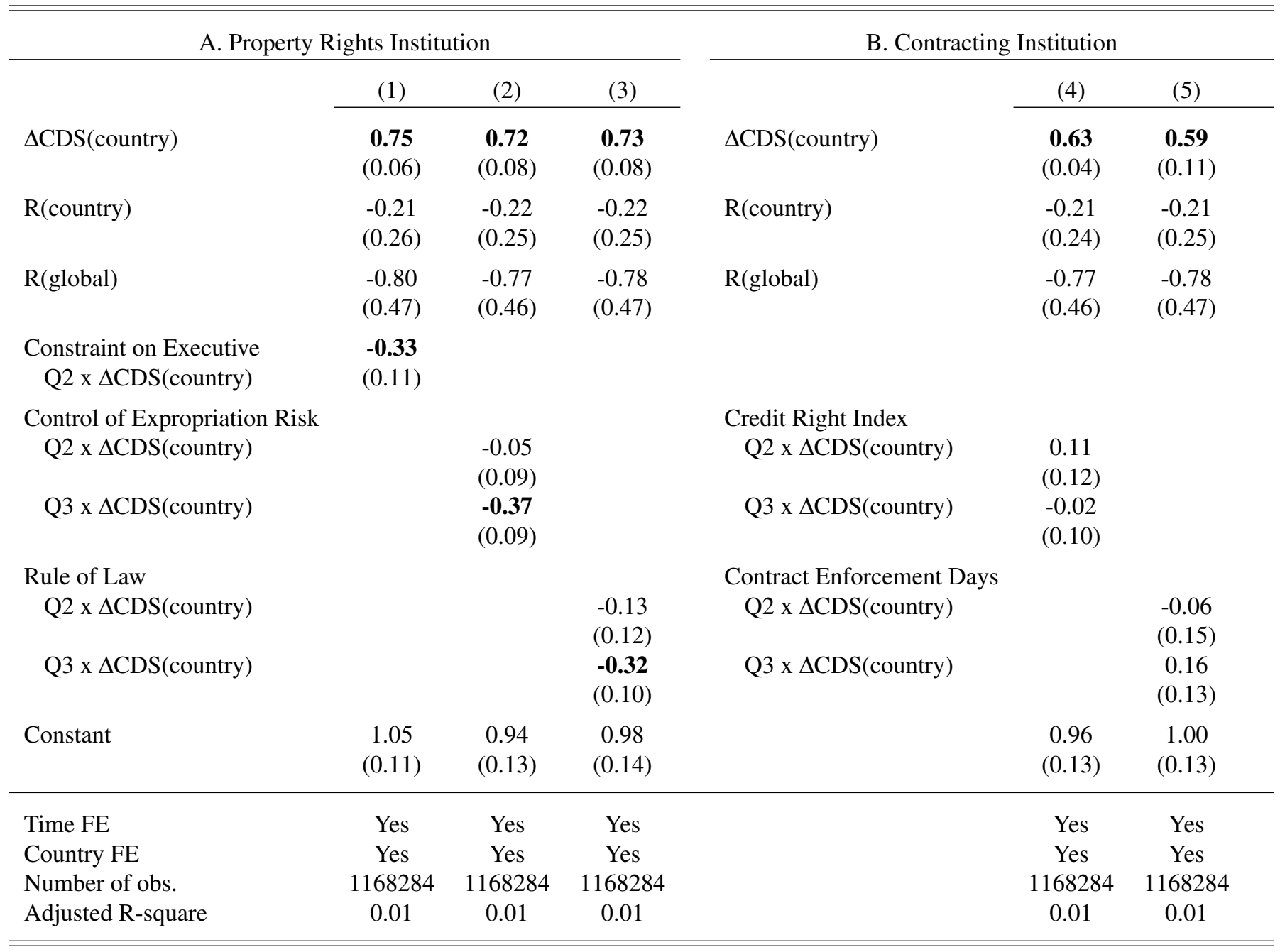




\section{Table 9: Controlling for Lagged Sovereign Spreads}

The table presents results of the following panel regression:

$\operatorname{DeltaCDS}_{i, k, t}=\alpha_{i}+\delta_{t}+\sum_{s} \beta_{s}$ Inst $_{s, k} \cdot \Delta C D S_{k, t}+\beta_{0} \Delta C D S_{k, t}+\beta_{1} w \Delta C D S_{k, t-5}+\beta_{2} w \Delta C D S_{k, t-10}+\beta_{4} w \Delta C D S_{k, t-20}+\varepsilon_{i, k, t}$.

Standard deviation is reported in the parentheses. Regression coefficients that are statistical significant at the 5 percent level are in bold script. The sample period is from January 1, 2008 to February 10, 2010.

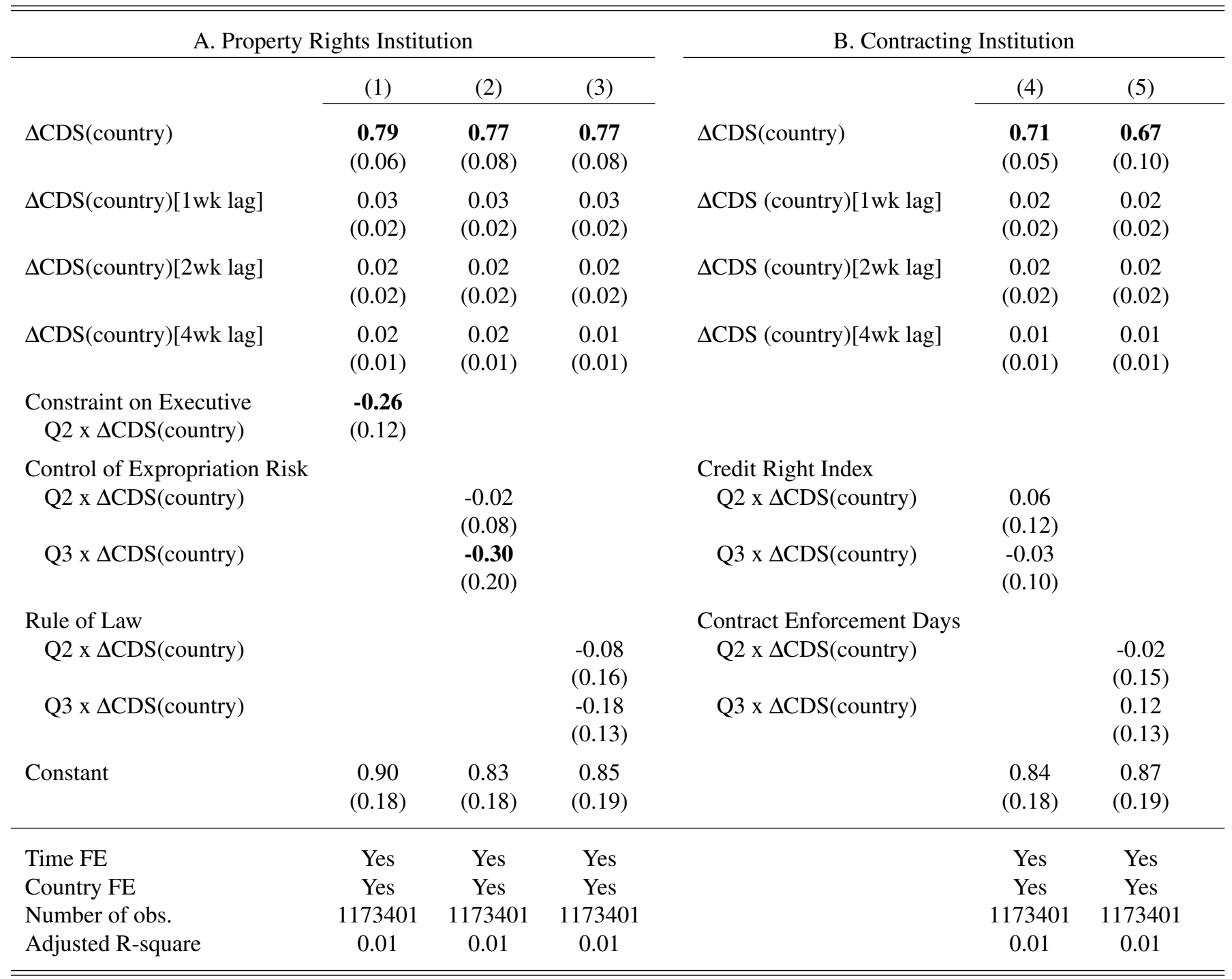


Figure 1: Panel A. Sovereign and Corporate CDS Index - North America

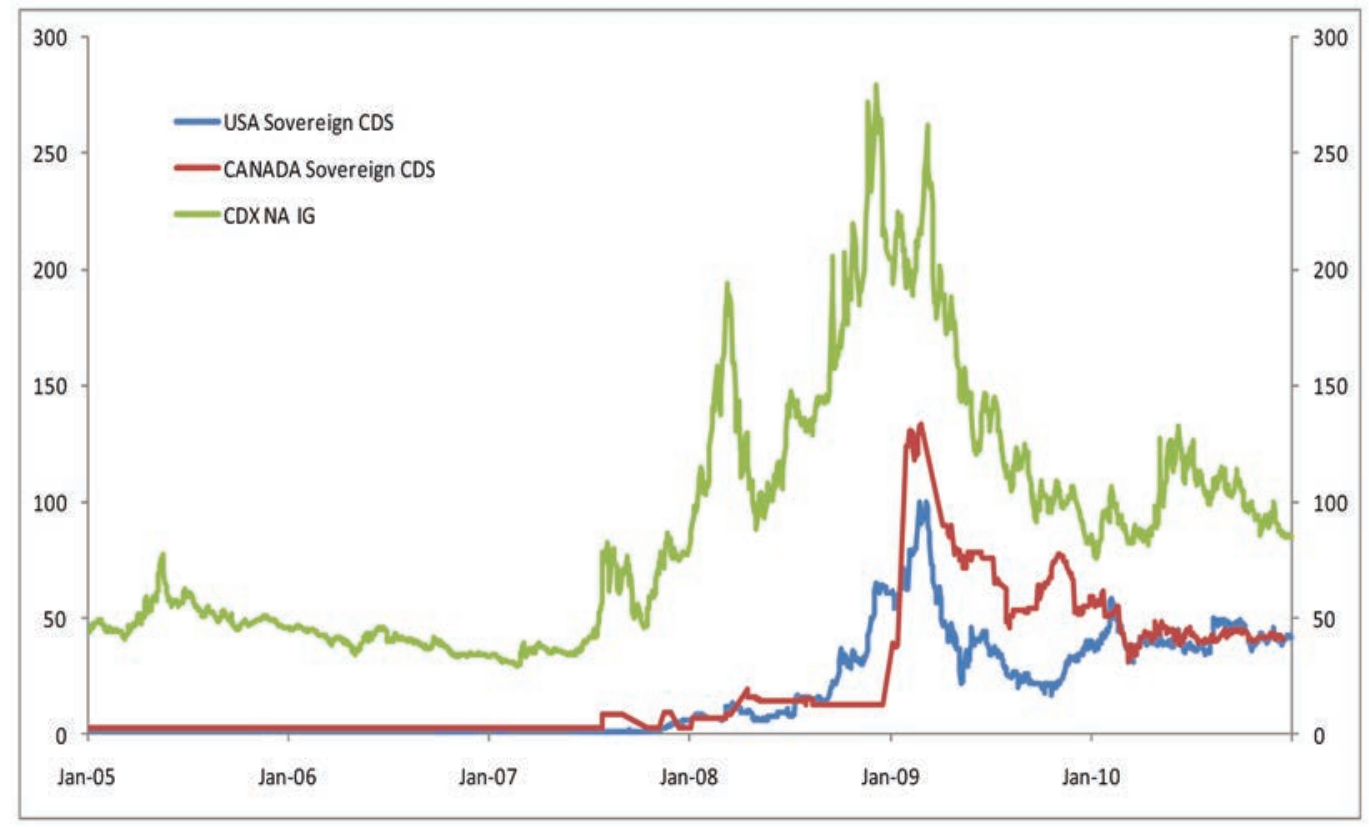

Panel B. Sovereign and Corporate CDS Index - Europe

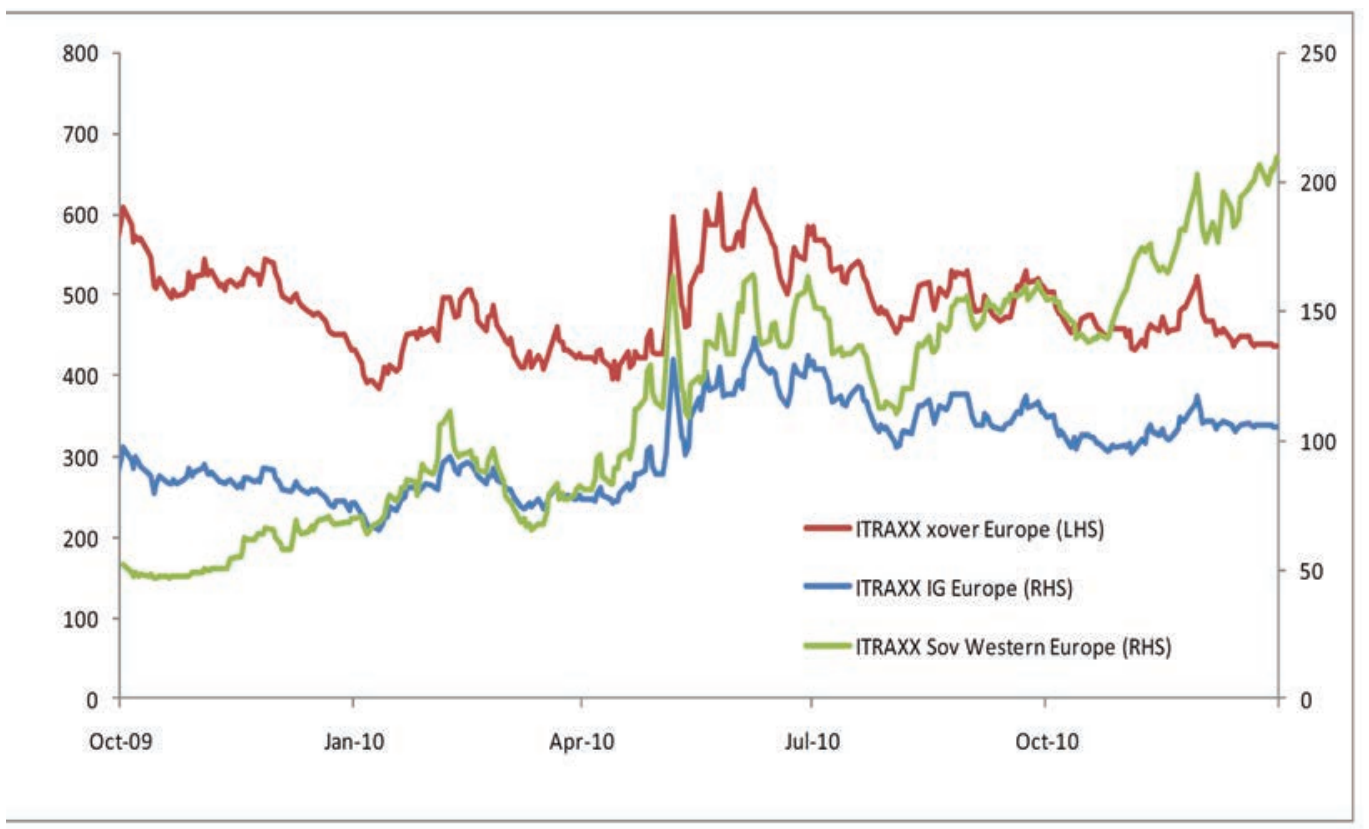




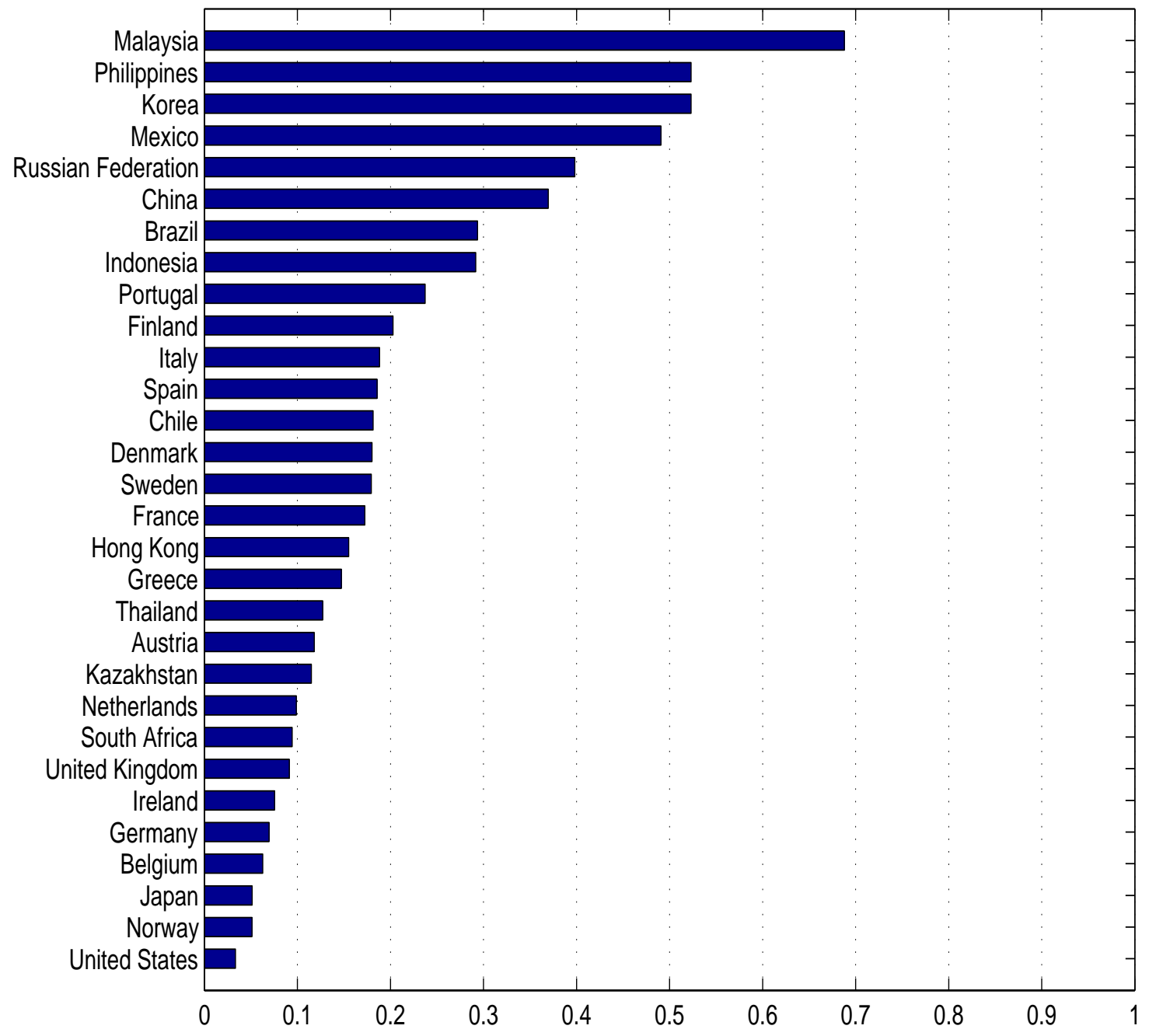

Figure 2: Correlations between Corporate CDS and Sovereign CDS, $\rho=$ $\operatorname{corr}(\triangle C D S($ firm $), \triangle C D S($ country $))$ 
(a) Austria

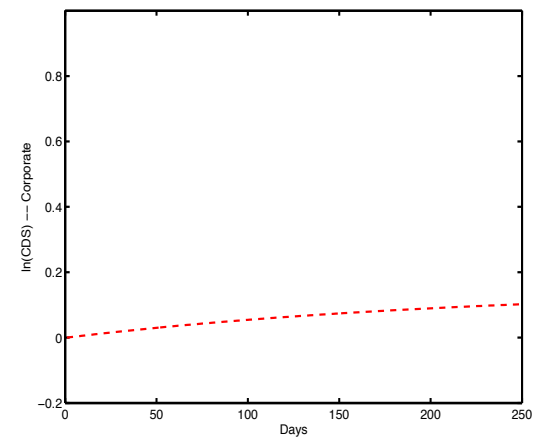

(d) Finland

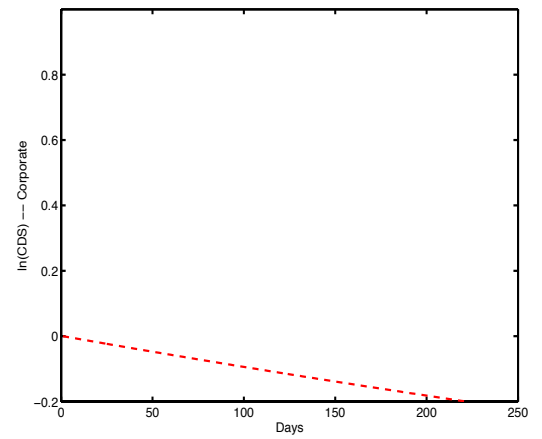

(g) Japan

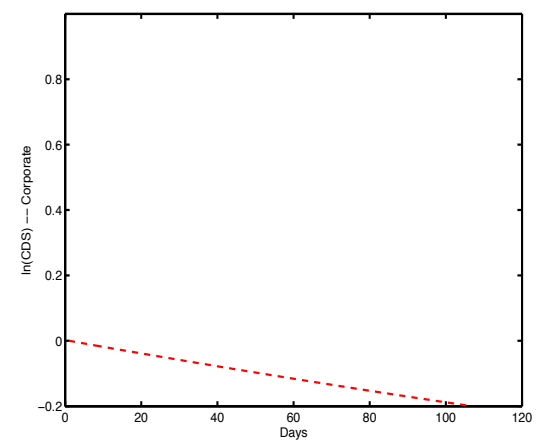

(j) UK

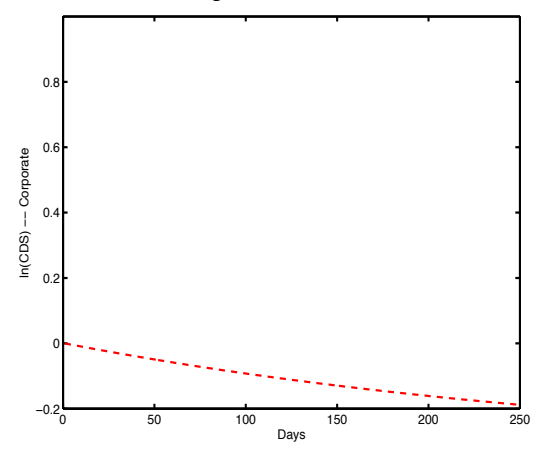

(b) Belgium

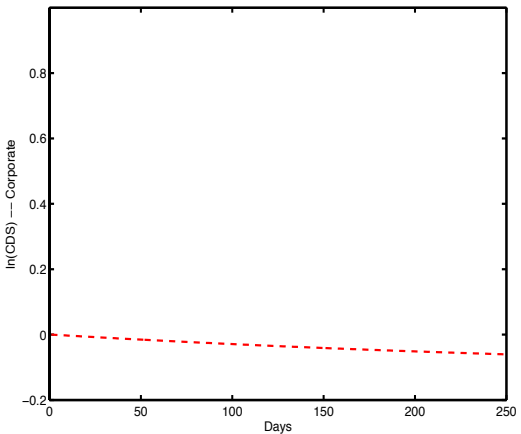

e) Germany

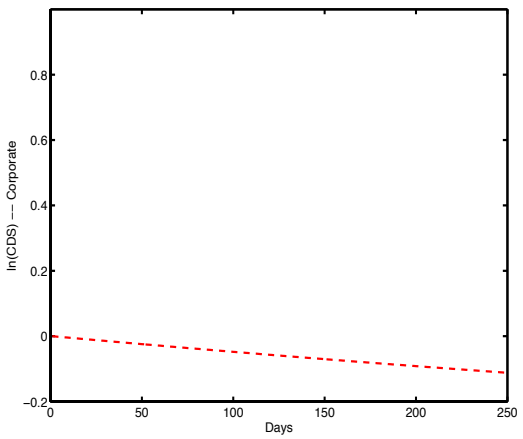

(h) Netherlands

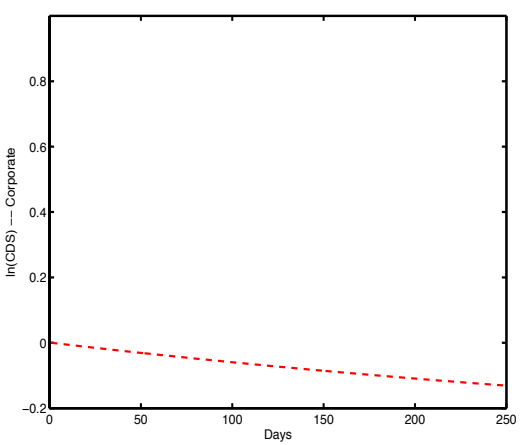

(k) US

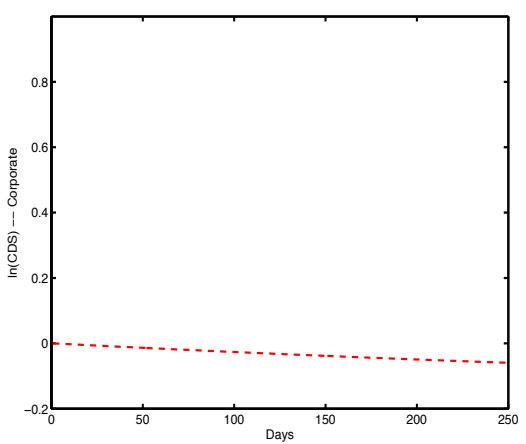

(c) Denmark

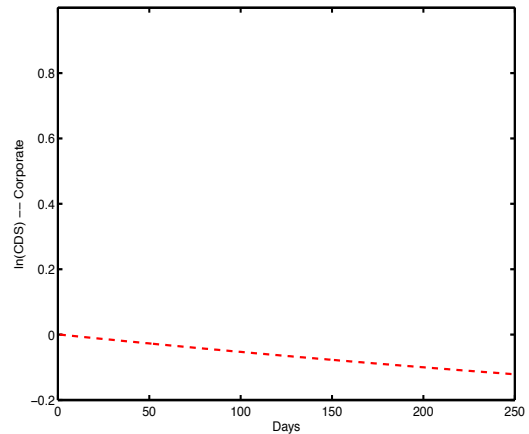

(f) Ireland

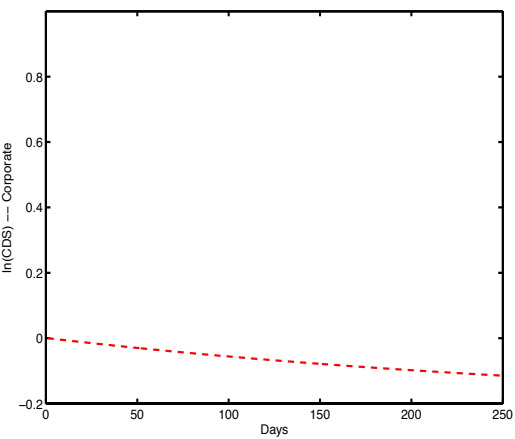

(i) Norway

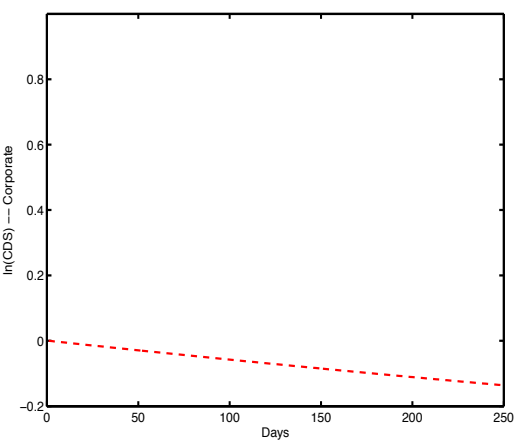

Figure 3: Impulse response functions for countries with good property rights institutions (Group 1 in Table 2). The estimates are based on the vector error correction models in Table 5. 
(a) Brazil

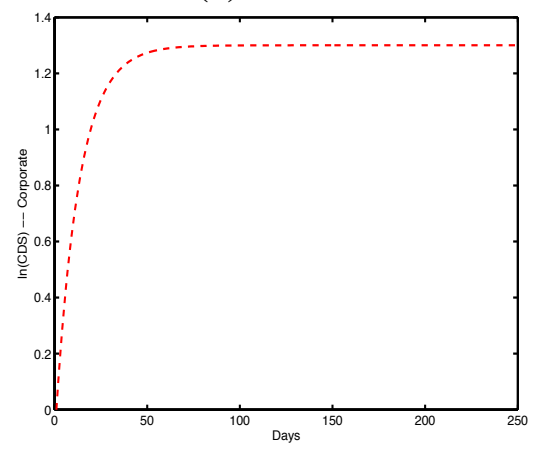

(d) Kazakhstan

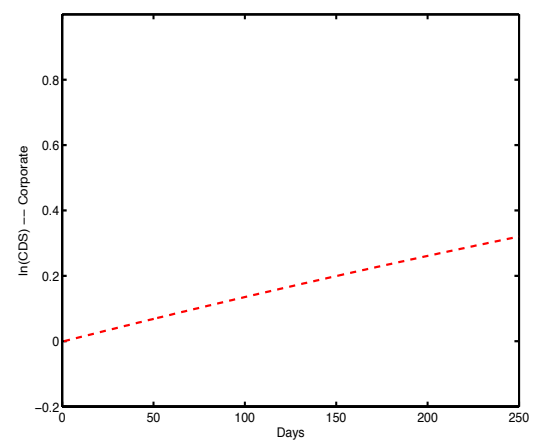

(g) Mexico

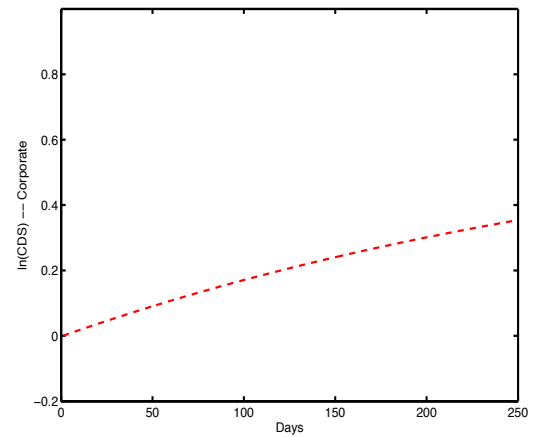

(b) China

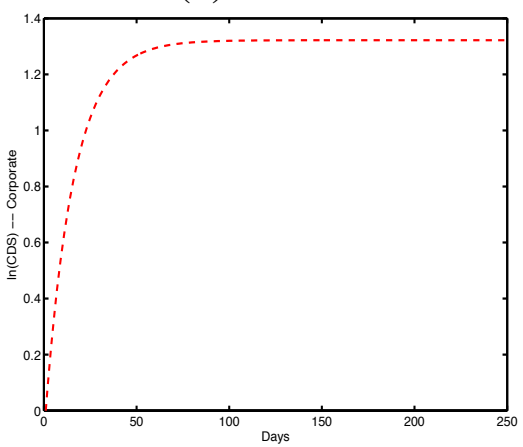

(e) Korea

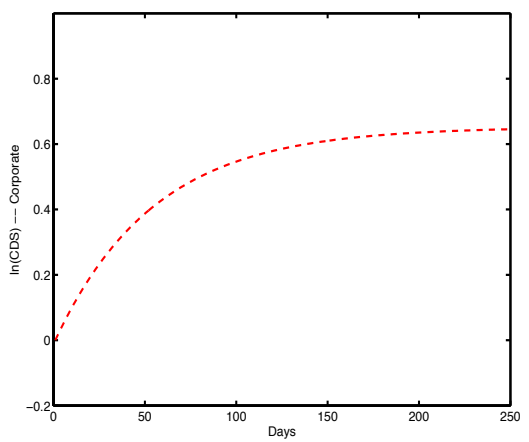

(h) Philippines

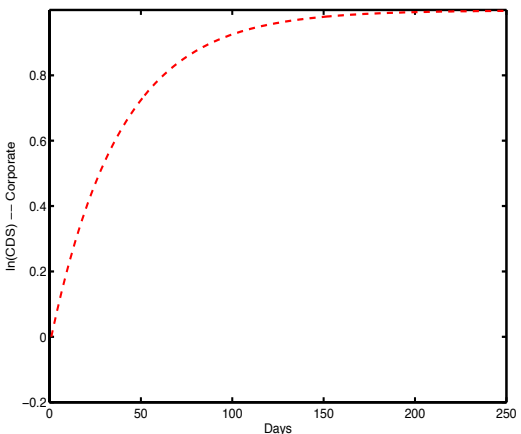

(j) Thailand

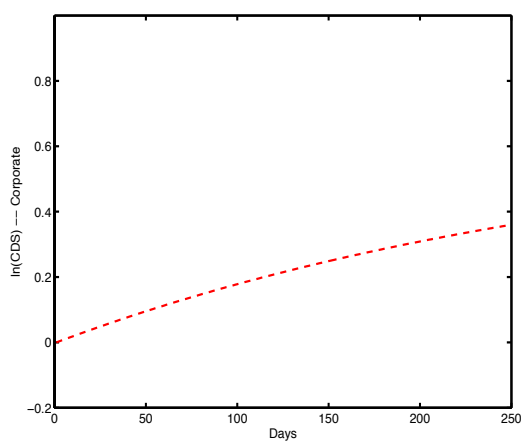

(c) Indonesia

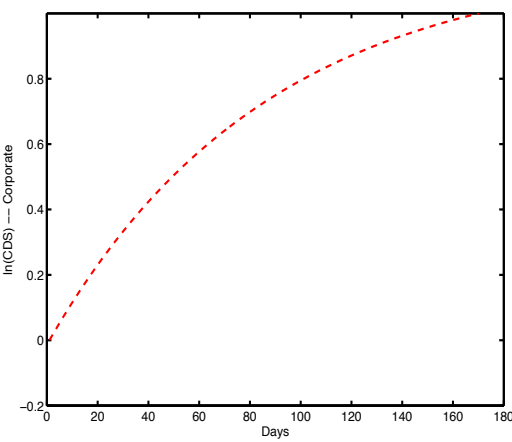

(f) Malasia

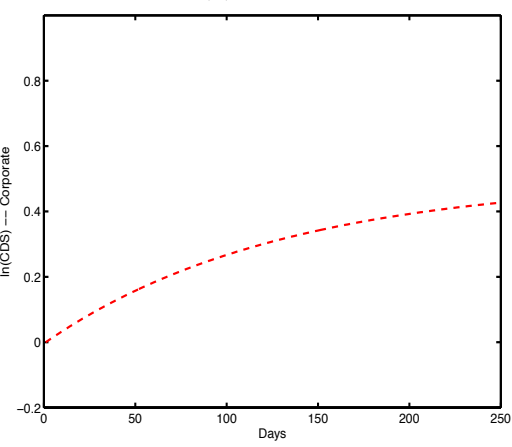

(i) Russia

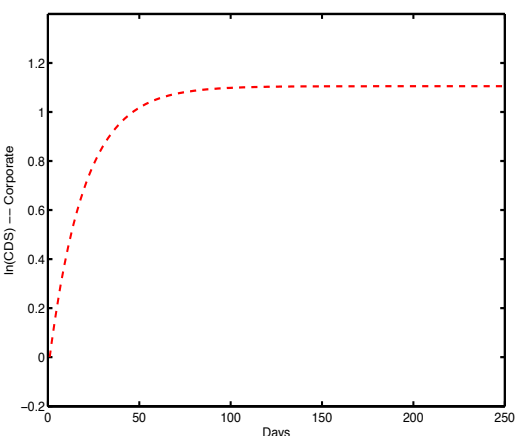

